\title{
ADMINISTRATIVE EQUITY: AN ANALYSIS OF EXCEPTIONS TO ADMINISTRATIVE RULES
}

\author{
Alfred C. Aman, JR.*
}

For many years courts have struggled to reconcile "life by strict law with equity in the particular case."1 They have tempered ostensibly clear rules of law by invoking such substantive equitable principles as estoppel, unjust enrichment, fraud, and duress. ${ }^{2}$ Courts have also used their equitable powers to fashion broad remedial relief, particularly when the legislature has abdicated its policymaking role. These cases often involve structural injunctive relief designed to carry out the mandates of the Constitution. ${ }^{3}$ In exercising this kind of power, federal courts have often used the due process and equal protection clauses of the Constitution as broad delegations of legislative power to devise rules and regulations to integrate schools, ${ }^{4}$ to reforin the conditions and treatment of prisoners ${ }^{5}$ and mental patients, ${ }^{6}$ to reapportion legislative districts, ${ }^{7}$ and to achieve other broad policy goals. ${ }^{8}$

* Associate Professor of Law, Cornell Law School; A.B., University of Rochester, 1967; J.D., University of Chicago, 1970. I would like to acknowledge my indebtedness to Professors Greenhouse, Hanslowe, Kent, Lyons, Osgood, Polsby, and Summers, who provided helpful comments and criticism. I would also like to thank Barry Wold and Richard Edwards, 1981 graduates of Cornell Law School, and Deborah Skakel and Hirokazu Tangiguchi, members of the class of 1983 of Cornell Law School, for their valuable and dedicated research assistance.

1. See Summers, General Equitable Principles Under Section 1-103 of the Uniform Commercial Code, 72 Nw. U. L. Rev. 906 (1978).

2. See id. 913-23.

3. See generally O. Fiss, INuUnCTions 415-76 (1972).

4. See, e. g., Swann v. Charlotte-Mecklenburg Bd. of Educ., 402 U.S. 1 (1971) (busing is one of several remedies that can be used to achieve integration).

5. See e. g., Finney v. Hutto, 410 F. Supp. 251 (E.D. Ark. 1976), affd, 548 F.2d 740 (5th Cir. 1977) (during punitive isolation of prisoners, it is unconstitutional to confine more than two prisoners to a single cell, deny prisoners reasonable and necessary medical care, put prisoners on a "gruel" diet, or hold prisoners in isolation for more than $\mathbf{3 0}$ days).

6. See, e.g., New York State Ass'n for Retarded Children, Inc. v. Carey, 393 F. Supp. 715 (E.D.N.Y. 1975) (approving the consent judgment settling the Willowbrook case, New York State Ass'n for Retarded Children, Inc. v. Rockefeller, 357 F. Supp. 752 (E.D.N.Y. 1973), and requïring the institution to provide an individual "development plan" for patients and six hours of daily activity related to imdividual objectives); Wyatt v. Stickney, 344 F. Supp. 373 (M.D. Ala. 1972), affd sub nom. Wyatt v. Aderholt, 503 F.2d 1305 (5th Cir. 1974) (holding that civilly committed mentally handicapped persons have a "right to treatment" and that the Constitution requires a minimum quality of care or treatment, even if the mentally handicapped person was confined ouly because of his "need for care").

7. See, eg., Baker v. Carr, 369 U.S. 186 (1962).

8. See, e.g., Gautreaux v. Chicago Housing Auth., 304 F. Supp. 736, $738-39$ (N.D. Ill. 1969) 
The exercise of substantive and remedial equity is not confined solely to federal and state courts, the usual domam in which it is studied, Administrative agencies have developed analogous principles and processes to fulfill their various legislative mandates. Agencies at all levels often seek to do equity in particular cases by entertaining requests for exceptions to regulatory legislation or to agency rules. ${ }^{9}$ There is a need for a procedural mechanism to consider individual requests for exceptions to administrative rules of general applicability even under relatively straightforward regulatory programs. Such a mechanism is particularly necessary when the program in question imvolves complex economic, environmental, health, and safety problems that cut across several industries.

General rules cannot account for all possible situations. Given the circumstances of a particular party in a particular case, a rule may demand what is technologically or economically impossible, or it inay require a party to incur regulatory costs that greatly outweigh the social benefits of compliance. In some cases, comphiance may actually undermine the purposes and goals of the rule itself. Similarly, an agency may find that the intent of a rule can best be furthered by ineans that the rule itself seemingly prohibits. ${ }^{10}$ Usually, enabling acts or an agency's own rules exphicitly establish processes and criteria under which administrators can do justice in individual cases. ${ }^{11}$ Soine courts have sug-

(ordering the Housing Authority to build its next 700 family units in predoninately white areas outside Chicago or in Cook County), modifed, Gautreaux v. Landrieu, 498 F. Supp. 1072 (N.D. IIl. 1980). See generally Fiss, The Supreme Court, 1978 Term-Foreword: The Forms of Justice, 93 HARV. L. REv. 1 (1979).

9. In addition to requests for exceptions, agencies have other procedures, including interpretations, rulings, and no-action letters, conforming broad regulatory rules to individual circumstances. For a discussion of these various procedural devices see text accoinpanying notes 36.49 infra.

10. See, e.g. Occupational Safety and Health Act of 1970, 29 U.S.C. §655(d) (1976), which provides that an employer may obtain a permanent variance upon proof that "the conditions, practices, means, inethods, operations, or processes used . . . by an employer will provide employment and places of employment to his employees which are as safe and healthful as those which would prevail if he comphed with the standard." See generally Morey, Mandatory Occupational Safety and Health Standards-Some Legal Problems, 38 LAW AND ConTEMP. PRoBs. 584, 594-95 (1974).

11. Several statutes authorize an administrator to grant or deny adjustments to rules of general applicability. Some statutes only authorize the administrator to grant exceptions to rulcs. Such exceptions must be consistent with purposes of the act under which the rule was promulgated. See, e.g., Natural Gas Policy Act of 1978, 15 U.S.C. \& 3412(c) (Supp. IV 1980). As commentators have observed:

A key qualification in section 502(c) of the [Natural Gas Policy Act] is that relief from a rule or order may be granted only if "consistent with the other purposes of this Act. . ." This factor is important because it clearly indicates that individual relief proceedings may not be viewed in isolation. In every case in which relief is granted, the 
gested that the authority to grant exceptions to rules may be implied as well. ${ }^{12}$

Commission must consider the full implications of the precedent it is setting, including the size of the class of similarly situated persons and the policy implications of extending relief to the entire class.

Noland \& Penniman, The FERC Adjustments Process Under Section 502(c) of the Natural Gas Policy Act of 1978, 1 ENERGY L.J. 79, 95 (1980).

Other statutes are less explicit but similarly authorize adjustments to certain rules. See, e.g., 15 U.S.C. \$ 766(b) (Supp. IV 1980). Still other statutes authorize adjustnents to explicit provisions of the statutes itself. See, e.g., Powerplant and Industrial Fuel Use Act of 1978, 42 U.S.C. $\$ \$ 8321,8351$ (Supp. III 1979), partially repealed by the Omnibus Reconciliation Act of 1981, Pub. L. No. 97-35, 95 Stat. 357. Finally, the proposed bill to create an Energy Mobilization Board would have established an agency whose primary responsibility would have been to waive or exempt certaim petitioners from a variety of legal requirements imposed by various federal, state, and local statutes, rules, and regulations. See Priority Energy Project Act of 1980, S. 1308, 96th Cong., 2d Sess., amended in conference, H. R. REP. No. 96-119, 96th Cong., 2d Sess. (1980).

These statutes suggest equitable criteria that vary considerably. Sone statutes set forth broad criteria givmg the administrator enormous discretion in applying the standards. A petitioner may be entitled to adjustments to rules issued under statutes regulating the price and allocation of domestic crude oil, for example, if he can show "special hardship, mequity or unfair distribution of burdens." See Department of Energy Organization Act, 42 U.S.C. § 7194(a) (Supp. III 1979). The Natural Gas Policy Act of 1978 uses the same standard for prices established for natural gas both at the wellhead and at the consumer level. See 15 U.S.C. \$3412(c) (Supp. IV 1980). Other acts specify more explicitly when adjustments should or sliould not be granted. See note 10 supra. The Occupational Safety and Health Act provides that an employer may obtain a permanent variance from a safety and health standard. The Secretary may also grant variances to allow "reasonable variances, tolerances, and exemptions" from any provisions of the Act "as he may find neccssary and proper to avoid serious impairment of the national defense." 29 U.S.C. § 665 (1976). Finally, under OSHA, an employer may receive a temporary variance (not inore than one year, renewable twice) on proof that "he is unable to comply with a standard by its effective date because of unavailability of professional or technical personnel or because necessary construction or alteration of facilities cannot be completed by the effective date." Id. $\S 655(\mathrm{~b})(6)(\mathrm{A})$. For a general discussion of variance provisions within OSHA, see Currie, OSHA, 1976 AM. B. FouND. RESEARCH J. 1107, 1151-53.

Several other statutes also provide for exceptions, variances, modifications, or exemptions. See, e.g. , Federal Trade Traffic Safety Act, 15 U.S.C. \$\$ 1410, 1417 (1976); Federal Mime Safety and Health Act of 1977, 30 U.S.C. § 811(c) (Supp. III 1979); Coal Mme Health and Safety Act of 1969, 30 U.S.C. $\$ \S 811(\mathrm{e}), 814(\mathrm{~g})$ (Supp. III 1979); Federal Water Pollution Control Act Amendments of 1972, 33 U.S.C. $\S 1342$ (1976); Safe Drinking Water Act, 42 U.S.C. $\$ 300 \mathrm{~g}-4$ (1976); Nuclear Non-Proliferation Act of 1978, 42 U.S.C. \$2155a (Supp. III 1979); Clean Air Act Amendments of 1970, 42 U.S.C. $\$ 7410$ (Supp. III 1979); Shipping Act of 1916, 46 U.S.C. $\$ \S 814$, 833a (1976); Communications Act of 1934, 47 U.S.C. $\$ \S 203(b)(2), 214$ (a) (1976) (comnon carriers) and 47 U.S.C. $\$ \S 316,359$ (1976) (radio); Interstate Comnierce Act, 49 U.S.C. $\$ 304(a)(4 a)$ (1976); Federal Aviation Act of 1958, 49 U.S.C. \$§ 1386(b)(1), 1421(c) (1976).

Finally, the agencies' own rules or policy statements often provide exceptions authority and criteria. See, e.g., F.P.C. Order No. 467, discussed in Pacific Gas \& Elec. Co. v. FPC, 506 F.2d 33, 52 (D.C. Cir. 1974) ("The priorities-of-deliveries set forth above will be applied to the deliveries of all jurisdictional pipeline compames during periods of curtailment on eacls company's system; except, however, that upon a finding of extraordmary circumstances . . . exceptions to those priorities may be permitted.")

12. See, eg., WAIT Radio v. FCC, 418 F.2d 1153 (D.C. Cir. 1969), cert. denied, 409 U.S. 1027 (1972): 
This article will develop the concept of administrative equity by showing that certain equitable forces, often thought to be outside the law, are very much at work in the regulatory arena and that exceptions granted to rules of general applicability are not necessarily random in nature. Exceptions tend to fall within a number of categories and are grounded on distinct equitable norms. This article provides a rhetorical map of the equitable maxims that make up the terram of administrative equity. These maxims do not necessarily represent principles of justice, but they do articulate administrators' reasons-largely implicit-for granting or denying exceptions. An examination of the norms that underlie these maxims suggests an ongoing dialogue annong narket, regulatory, and agency values that allows contradictions within regulatory schemes and between regulatory schemes and market forces to coexist. In conclusion, this article demonstrates how administrative equity might operate within regulatory settings that rely heavily or exclusively on market forces.

\section{ADMINISTRATIVE EQUITY}

\section{A. The Concept and Development.}

Administrative equity serves as a bridge between collectively determined rules and the reality of the particular case. It refers to the substantive principles and norms that inay justify individual exceptions to rules of general applicability. Administrative equity is thus primarily concerned with the impact of a regulatory scheme on those required to bear the regulatory costs. An entity whose pollution exceeds the maximum level allowed under a certain regulation may, for exainple, seek a temporary exemption from comphance while the necessary pollution-control equipinent is installed. ${ }^{13}$ Similarly, an oil producer bound by maximum pricing regulations may seek an exception to these rules when the regulated price is so low that it is no longer profitable to operate certain wells. ${ }^{14}$ The primciples used by regulators to grant or

[A]n application for waiver las an appropriate place in the discharge by an administrative agency of its assigned responsibilities. The agency's discretion to proceed in difficult areas through general rules is intimately linked to the existence of a safety valve proce-

dure for consideration of an application for exemption based on special circunstances. 418 F.2d at 1157 (citations omitted). The court also noted that "provision for waiver may have a pivotal importance in sustaining the system of administration by general rule." Id. at 1158. See also United States v. Storer Broadcasting Co., 351 U.S. 192, $204-05$ (1956) (quoting National Broadcasting Co. v. United States, 319 U.S. 190, 225 (1943)). But see FCC v. WNCN Listeners Guild, 450 U.S. 582, 601 n.44 (1981).

13. See notes 100-107 infra and accompanying text.

14. Many of the examples of administrative equity are drawn from the defunct oil price and allocation controls program authorized $\S \S$ by the Emergency Petroleum Allocation Act of 1973, 15 U.S.C. $\$ \$ 751-760$ (1976) (amended 1974, 1975, 1976, 1980). This program was administered by 
deny such requests constitute administrative equity. These principles allow the administrator "to rectify the shortcoming . . . of the lawgiver due to the generahity of his statement." 15

Administrative equity thus differs from the equitable justifications for regulating in the first imstance. ${ }^{16}$ It may be argued, for example, that to allow the price of United States oil to be set at the world price would be mequitable because domestic producers would reap windfall profits as a result of the actions of a foreign cartel. ${ }^{17}$ Similarly, it may be argued that governmental protection is necessary to bolster the bargaining power of consumers or employees whose position is inherently inequitable vis $a$ vis large corporate entities. ${ }^{18}$ The concept of administrative equity does not, however, provide a rationale for instituting a general regulatory scheme; rather, administrative equity is concerned with "a rectification of law where law falls short by reason of its universality"19-however equitable the overall purpose of the universal or general rules involved.

The development of administrative jurisdiction over cases challenging the applicability of general rules to particular situations is analogous to the development of jurisdiction in the English Court of Chancery over two types of cases described by Professor Maitland.

the Federal Energy Agency, whose functions were later incorporated into the Department of Energy. For a procedural history of this program, see Aman, Institutionalizing the Energy Crisis: Some Structural and Procedural Lessons, 65 CORNELL L. REv. 491, 526-44 (1980).

The oil price and allocation program spawned a very active exceptions process for a number of years and developed an elaborate jurisprudence of exceptions. See, e.g., TASK FORCE ON REForm of Federal ENERgy AdMINISTRATION, Federal ENERgy ADMINISTRATION REgulaTION 107-37 (P. MacAvoy ed. 1977).

15. ARISTOtLe, Nicomachean Ethics, Book 5, at 142 (M. Ostwald trans. 1962).

16. Assessing the wisdon of congressional lcgislation and administrative rules themselves is beyond the scope of this article. Professor Newman has commented on the various meanings of the word "equity":

The relationship between law and equity in modern times has never becn clearly established, and the nature of equity remains shrouded in inystery. The search for the meaning of justice which began in the corridors of the Acadeiny of Athens is still an unfinished story. Much of the uncertainty which surrounds the incaning of equity is due to the fact that law inust balance the interests of the individual against the interests of society and each set of intcrests is differently affected by moral codes. . . .

It is probably because of dichotoiny between the goals of social order and individual justice that the word "equity" and its various synonyms are used in two widely different senses; in the general sense of what is fair and just which is the objective of all law, and in the specific sense of an eleinent of law which introduces distinctive ethical values into the legal norms.

EQUITY IN THE WORLD'S LEGAL SYSTEMS 15 (R. Newman ed. 1977).

17. See, e.g., Windfall Profits Tax and Energy Trust Fund: Hearings Before the House Comm. on Ways and Means, 96th Cong., 1st Sess. 19 (1979) (statement of Treasury Secretary William Blunenthal reciting this argument for a windfall profits tax).

18. See generally Breyer, Analyzing Regulatory Failure: Mismatches, Less Restrictive Alternatives, and Reform, 92 HARv. L. REv. 549, 559 (1979).

19. ARISTOTLE, supra note 15, at 142. 
One type involved petitions that sought justice im individual cases from or against the "king":

Many of these petitions . . . seek for justice not merely from the king but agamst the king. If anybody is to be called the wrong doer, it is the king himself. For example, he is in possession of land which has been seized by his officers as an escheat while really the late tenant has left an heir. Now the king can not be sued by action-no writ will go against him; the heir if he wants justice must petition for it humbly. Such matters as these are referred to the Chancellor. ${ }^{20}$

In the administrative context, the king appears in the form of a secretary, commissioner, or administrator. The "injustices" perpetrated by the king usually involve the imposition of excessive or unnecessary regulatory costs arising from allegedly overbroad rules. In theory, petitions challenging administrative rules of general applicability lie against the administrative king; however, when the challenge is that the rule as applied to a particular entity is unreasonable, the likelihood of prevailing on the merits is slight. The "king" cannot be effectively sued in cases in which the complaint is that the general should not apply to the particular.

Seeking individual exceptions to administrative rules is similar to the development of Chancery jurisdiction over a second type of case described by Professor Maitland. In these cases, the Chancellor intervened because the petitioner could not obtain an effective remedy at common law: "Very often the petitioner requires soine relief at the expense of some other person. He complains that for some reason or another he can not get a remedy in the ordmary course of justice and yet he is entitled to a remedy."21 Although in the administrative setting such claims are brought against the "king" rather than agamst another individual, often the relief granted is "at the expense of some other person." If, for example, one firm is allowed to sell its oil at a price higher than its competitors' prices, or is allowed additional time to in-

20. F. MAITLAND, EQUiTY, 4 (A. Chaytor \& W. Whittaker eds. rev. by J., Brunyate 1936).

21. Id. 4-5. Professor Maitland tells of the way such petitioners often described themselves:

$\mathrm{He}$ is poor, he is old, he is sick, his adversary is rich and powerful, will bribe or will intimidate jurors, or has by some trick or some accident acquired an advantage of which the ordinary courts with their formal procedure will not deprive him. The petition is often couched in piteous terms, the king is asked to find a remedy for the love of God and in the way of charity.

MAITLAND, supra note 20, at 4. In fact, legal historians have noted that Chancery jurisdiction did not arise because of the piteous terms in which the petitioners described themsclves and thus the need to do equity in any general sense, but primarily from the need to address two serious deficiencies in the common law: its refusal to recognize uses and the requirement of a scal. See, e.g., Avery, The History of the Equitable Jurisdiction of Chancery before 1460, BuLL. INST. HIST. RESEARCH 129,134-35 (1969). It is in this sense that the inability of judicial review to deal effectively with specific problems caused by valid administrative rules and statutes is analogous to the development of Chancery jurisdiction. 
stall pollution control devices, relief is in effect at the expense of those to whom the general rules continue to apply-the petitioner's competitors. Moreover, just as the inadequacy of the common law courts to provide necessary remedies contributed to the rise of the Enghish Court of Chancery, ${ }^{22}$ the inadequacy of judicial remedies for administrative equitable claims gives rise to a similar institutional need in modern times.

The inability of judicial review of administrative action to provide mdividualized rehef is attributable to established constitutional and administrative law doctrines. Legislatures enjoy enorinous discretion when devising regulatory statutes, particularly in the area of economic regulation. When a hitigant asserts that an economic regulation is unconstitutional, the test apphed is whether there is a rational basis for the legislature's action. ${ }^{23}$ The use of a rational-basis test almost ensures that the statute will be upheld. Thus, attacks on the overall reasonableness of an economic regulatory statute almost never succeed. ${ }^{24}$ There is usually no basis for constitutional attack when economic legislation is classified im a plausible way, despite its unequal impact on some or its unreasonableness as applied to a particular party. In extreine cases, a constitutional clamı of taking might he, but the likelihood of success in such cases is remote. ${ }^{25}$ Generally, courts look to the overall scope and purpose of the statute, not to its individual impact. ${ }^{26}$

Similarly, the substantive validity of rules proinulgated by an agency traditionally has been subject to a two-pronged test that presumes the validity of the rule. ${ }^{27}$ The first question is whether the

22. See note 21 supra.

23. See Railway Express Agency v. New York, 336 U.S. 106 (1949).

24. See Williamson v. Lee Optical Co., 348 U.S. 483 (1955). Courts have seldom invoked the doctrine of substantive due process in the context of economic regulation since the demise of Lochner v. New York, 198 U.S. 45 (1905). See Nebbia v. New York, 291 U.S. 502 (1934).

25. See Pennsylvania Coal Co. v. Mahon, 260 U.S. 393 (1922). Although Pennsylvania Coal is still good law, "government regulation of commercial and industrial activity is today seldoun, if ever, found to constitute a taking where the regulation can rationally be related to the protection of public lrealth or some other substantial public welfare objective." R. STEWART \& J. KRIER, Environmental Law and Policy 455 (2d ed. 1978). See South Terminal Corp. v. EPA, 504 F.2d 646 (1st Cir. 1974), where the court stated:

First, a particular use of a parcel of property may be regulated or forbidden. Second, all uses of a parcel inay be forbidden. Third, a right to use or burden property in a particular and permitted way may be transferred from the original owner to another person, or to a governmental body. Ouly the second and third situations are thought of as takings today.

Id. at 679 .

26. See, e.g., Railway Express Agency v. New York, 336 U.S. 106 (1949); Mapco Inc. v. Carter, 573 F.2d 1268 (Temp. Emer. Ct. App.), cert. denied 437 U.S. 904 (1978).

27. See Citizens to Preserve Overton Park v. Volpe, 401 U.S. 402, $415-16$ (1971). Over the years, numerous bills have been submitted in Congress which, if passed, would remove this pre- 
rule is within the agency's authority, as set forth in its enabling act. If it is, the rule is upheld unless it is "arbitrary and capricious and an abuse of discretion." 28 A corollary of the arbitrary-and-capricious standard is the maxim that "courts will not substitute their judgment for that of the administrator." 29 As a result, substantive attacks on the statute authorizing the regulation or on the rules promulgated pursuant to that statute usually have little chance of success. ${ }^{30}$ Though the king can be sued, it is often fruitless to try to invalidate a statute or a rule on the ground that it affects one or a few of those who are otherwise validly regulated in an arguably unreasonable manner.

There are, of course, other ways to challenge the validity of a rule as applied. The interested party can engage in prohibited conduct, be prosecuted, and then raise his pecuhar circumstances as a defense. The kinds of claims the accused may wish to make, however, are not likely to constitute a valid substantive defense to an enforceinent action, but will be more in the nature of a plea for inercy at the sentencing stage. ${ }^{31}$ This plea for mercy is cold comfort for those who believe that economic survival compels them to disregard or "aggressively interpret" the law involved.

sumption of validity. See, e.g., S. 111, 96th Cong., 1st Sess. (1979); S. 86 95th Cong., 1st Sess. (1977); S. 2408, 94th Cong., 1st Sess. (1975). This proposal is commonly known as the "Bumpers Amendment." It has stirred up a good deal of opposition for several reasons. See, e.g., Woodward \& Levin, In Defense of Deference: Judicial Review of Agency Action, 31 AD. L. REv. 329 (1979). To the extent this proposal is, in fact, based on the need to "force agencies" to think through all of the effects of a rule, including its impact on various imdustries and firms withm those industries, an active exceptions process may be a preferable way of ensuring the fine tuning that any regulatory program requires. Indeed, given the inherent limitations of general rules, however carefully conceived and crafted, providing for administrative equity would deal with problems of overbreadth and unnecessary cost without undermining so basic a premise of the administrative process as the presumption of validity of agency rules.

28. Citizens to Preserve Overton Park v. Volpe, 401 U.S. 404 (1970); 5 U.S.C. § 706(2)(A) (1976).

29. Citizens to Preserve Overton Park v. Volpe, 401 U.S. 404, 416 (1970).

30. Although the chance of success is shight, some attacks are effective. See, e.g., Home Box Office, Inc. v. FCC, 567 F.2d 9 (D.C. Cir.), cert. denied, 434 U.S. 829 (1977). Such cases are rare. But see S. Breyer \& R. Stewart, Administrative LaW and Regulatory Policy 289 n.86 (1979) ("There are signs that courts in recent years have been somewhat more willing to invalidate agency decisions as 'arbitrary and capricious' than previously, a developinent which may reflect the recent tide of criticism of agency 'failure', and growing skepticism of administrative claims of 'expertise." ").

31. See, e.g., Department of Energy guidelines explaining why the retroactive rehief exception should be judiciously granted: "One of the principal policy considerations underlying the ... . stringent position concerning retroactive exceptions is the danger that retroactive exceptions, by tending to ratify violatious of the FEA Regulations, may diminish the incentive which firns .. . have to learn the applicable law and even encourage noncompliance with the law." 41 Fed. Reg. 50,856, 50,861-62 (1976). 
Pre-enforcement judicial review offers a solution to the obey-orbe-prosecuted dilemma and an alternative to agency exception relief as well. Courts have limited this type of review, however, by requiring that hitigants exhaust administrative remedies before seeking pre-enforcement review. ${ }^{32}$ Even when pre-enforcement judicial review is available, the scope of the issues that may be raised usually is limited to issues of law. ${ }^{33}$

Fimally, there is a disguised way of challenging the applicability of a rule to a particular situation. One may raise procedural issues that apply to rulemaking in general, but that are really the result of substantive concerns. Such procedural challenges are often made to delay the application of a rule as much as to create an opportunity for a inore favorable substantive result. ${ }^{34}$ To the extent that administrative cquitable processes eliminate the need for some of these claims, the regulatory process benefits.

In short, courts generally liave not been receptive to legal arguments that seek to mvalidate a rule, particularly when the claim is that the rule in question appears unreasonablc when applied to one or a few of those it regulates. Such claims seldom rise to constitutional dimensions and rarely enable a court to conclude that the agency acted in an arbitrary or capricious manner. If such a "petitioner wants justice, he must petition for it liumbly. Such matters as these are referred to the Chancellor." 35 Just as equitable remedies were needed because common law remedies were often unavailable or too inflexiblc, administrative equity of a substantive nature is necessary because individualized judicial remedies are usually not available, pre-enforcement judicial review is often too limited, and prosecution is too high a price to pay for

32. See, e.g., Abbott Laboratories v. Gardner, 387 U.S. 136 (1967). Even so, pre-enforcement judicial review seems to be occurring with increasing frequency. See generally Allen, Thoughts on the Jeopardy of Rules of Long Standing to Procedural Challenge, 33 AD. L. REv. 203 (1981). Involving courts earlier in the oversight process demonstrates the need for administrative exceptions procedures, just as the legislative atteinpts to strip rules of their presumption of validity do. Though pre-enforcenent claims often involve a procedural clrallenge to rulemaking, the actual complaint usually involves the substantive impact of a rule on a particular entity:

[I]t weighs heavily on those whose interests are directly affected. In the classical case it puts all the members of an industry in a dilemma. They unust either comply with the regulation at some substantial cost or ignore or defy it and thereby court an enforceinent proceeding; the end result of that proceeding may be monetary penalties or other serious sanctions. No specific provision for judicial review covers the case. The coinpanies, or some of them, mvoke the general or special federal question jurisdiction of a district court and ask it to enjom enforceinent of the regulation and to declare it invalid. Id. 203-04.

33. See Abbott Laboratories v. Gardner, 387 U.S. 136 (1967).

34. See, e.g., Vermont Yankee Nuclear Power Corp. v. National Resources Defcnse Council, Inc., 435 U.S. 519 (1978).

35. MAITLAND, supra note 20 , at 4. 
noncomphance, particularly when it is unclear what may be pleaded as a defense. Many regulatory systems provide an explicit means of seeking equitable relief.

\section{B. "The Forms of Equitable Action."}

Administrative equity takes many forms. For exainple, the Department of Energy Act confers specific power on the Secretary to make "adjustments" to rules of general applicability. ${ }^{36}$ The term "adjustment" includes exceptions, exemptions, modifications, recissions, and intepretations. ${ }^{37}$ Similarly, other agencies provide opportunities for waiver, ${ }^{38}$ no-action letters, ${ }^{39}$ variances, ${ }^{40}$ or rulings. ${ }^{41}$ All of these "adjustments" provide, in lieu of enforcement proceedings, mechamisms for giving special meaning to rules of general applicability in particular cases.

Administrative adjustments fall into two broad categories. Soine are in the nature of declaratory judgments or advisory opinions. Rulings or interpretations, for example, generally determine whether a particular regulation applies to a certain set of facts and, if so, how.42 Usually, these determinations are made before any action has been taken and apply only to the petitioner. Similarly, rescissions and modifications apply to particular orders and particular petitioners. ${ }^{43}$ The

36. 42 U.S.C. $§$ 7194(a) (Supp. III 1979).

37. $I d$.

38. See, e.g., 47 U.S.C. $\S \S 203$ (b)(2), 316(a) (1976) (modification); 47 C.F.R. $\S 1.3$ (1981) (waiver procedure). See generally Anthony, Towards Simplicity and Rationality in Comparative Broadcast Licensing Proceedings, 24 STAN. L. Rev. 1, 90-91 (1971).

39. See, e.g., FED. SEC. L. REP. (CCH) I 66,481.10, stating the request procedure for a noaction letter under 17 C.F.R. $\$ 200.81$ (I981).

40. See, e.g., 29 U.S.C. $\S 665$ (1976).

41. [Code Vol.] FED. TAXES (P-H) ๆ 26,708 (authorization for rulings under section 7805 of the Internal Revenue Code). For an example of a typical ruling, see 110.222 I.R.S. Letter Rulings (CCH) LTR 8121003, January 26, 1981 (Nat'1 Office Technical Advice Memorandum applying Code Sec. 2503(b) and holding that the gift of nonvoting common stock is a gif of a present interest that qualifies for the annual exclusion provided by section 2503(b)).

42. See note 41 supra. The Federal Energy Administration defined "interpretation" as "a written statement . . . in response to a written request, that applies the regulations, rulings, and other precedents previously issued, to the particular facts of a prospective or completed act or transaction." 43 Fed. Reg. 14,436, 14,437 (1978).

43. See 10 C.F.R. \& 205.135(b) (1981), which provides:

(b) Criteria. (1) An application for modification or rescission of an order shall be processed only if-(i) the application demonstrates that it is based on significantly changed circumstances; and (ii) the 30-day period within which a person may file an appeal has lapsed or, if an appeal has been filed, a final order has been issued. (2) For purposes of this subpart, the term "significantly changed circuinstances" shall mean-(i) the discovery of inaterial facts that were not known or could not lave been known at the time of the proceeding and action upon which the application is based; (ii) the discovery of a law, regulation, interpretation, ruling, order or decision on appeal or exception that was in effect at the time of the proceeding upon which the application is based and 
second category of adjustments is similar to an injunction. The petitioner does not seek a clarification of how a rule applies; he seeks an order that the rule does not apply to him at all. In effect, this adjustment enjoins application of the rule to the petitioner. ${ }^{44}$

Injunction-like adjustinent processes are similar to law suits that seek to declare a statute unconstitutional as applied.45 A statute may be valid on its face, but when applied it may influence activity that it was not intended to affect. Administrative rules can fall into a similar category. A rule inay be valid on its face, and it may be properly promulgated; however, when applied to a particular petitioner or to a particular set of facts, it may cause "special hardship," "imequity," or an "unfair distribution of burdens." 46 Rigid adherence to the rule may not even advance the regulatory goals of the program. Though such concerns rarely rise to constitutional dimensions, they do raise serious questions within a regulatory frainework. Indeed, if strict application of the rule does irreparable harm to the petitioner and fails to accomphish any significant regulatory goals, the rule may well be "unconstitutional" within the regulatory framework that gave rise to it. ${ }^{47}$

Like injunctive relief, adjustments such as exceptions or variances are usually prospective. ${ }^{48}$ Retroactive relief is relatively rare and usually occurs only when the agency's own administrative delays make such relief appropriate. ${ }^{49}$ The petitioner thus need not confront the dilemma of either violatimg the law and risking prosecution or obeying the law and incurring the hardship that compliance may cause. An exception allows pre-enforcenent equitable relief at the administrative level without the risk of prosecution.

which, if such had been made known to the FEA, would have been relevant to the proceeding and would have substantially altered the outcome; or (iii) there has been a substantial change in the facts or circumstances upon which an outstanding and continuing order of the FEA affecting the applicant was issued, which change has occurred during the interval between issuance of such order and the date of the application and was caused by forces or circumstances beyond the control of the applicant.

44. The Department of Energy thus defined "exception," for the purpose of the defunct oil price and allocation controls program, as "the waiver or modification of the requirements of a regulatiou, ruling or generally applicable requirement under a specific set of facts." 10 C.F.R. $\S 205.2$ (1981). Of course, exceptions can also function like advisory opinions, particularly when they are denied.

45. See, e.g., Steffel v. Thonspson, 415 U.S. 452 (1974) (attempted application of a criminal trespass statute to petitioners eugaged in valid, first amendinent activities).

46. See, e.g., 42 U.S.C. § 7I94(a) (Supp. III 1979).

47. Sce authorities cited at note 186 infra.

48. See, e.g., 41 Fed. Reg. 50,856, 50,861 (1976) (standards for granting retroactive exception rehef are very stringent).

49. Id. 


\section{The Rise in the Need For Administrative Equity.}

Administrative-exceptions processes are not recent phenomena. Even under the simplest regulatory programs, the difficulty of formulating general rules that will properly and fairly apply to countless factual settings requires a regulatory fine-tuning capability. This capability has long been a part of the regulatory landscape. ${ }^{50}$ When agencies have granted such exceptions, however, the relief has usually been narrow and applicable only to the petitioner. ${ }^{51}$ A strong case can be made for the need for a more active and more principled exceptions process in all regulatory areas.

Much of the regulation passed during or shortly after the New Deal is quite specific, compared to more recent regulation. ${ }^{52}$ The Civil Aeronautics Board was established to regulate airlines; ${ }^{53}$ the Federal Communications Cominission dealt with communications; ${ }^{54}$ the Federal Power Cominission, at least initially, focused on natural gas pipelines and on wholesale electric utility rates; ${ }^{55}$ and the Securities Exchange Commission focused primarily on the securities industry. ${ }^{56}$ The Interstate Commerce Cominission, a forerunner of these agencies, first focused primarily on railroads and only later on trucks and oil pipelines. ${ }^{57}$ These agencies regulate primarily on a case-by-case basis and are directly responsible for the preservation and furtherance of "the public interest."s8 This usually translates into a concern not only

50. The classic example of variances or exceptions in an administrative context is their use in zoning. The generality of local zoning ordinances requires the fine-tuning capability that use and area variances provide and helps prevent devaluation of property. See generally 3 R. ANDERSON, AMERICAN LAW OF ZoNING \$§ 18.01-18.58 (2d ed. 1977); Comment, Variance Law in New York: An Examination and Proposal, 44 ALB. L. Rev. 781 (1980).

51. This was clearly not the case, howevcr, with the exceptions process administered by the Department of Energy during the era of oil price and allocation control regulation. An elaborate jurisprudence regarding exceptions developed over time, in large part because those processes were extremely active. Those processes became a primary policy-1naking device for the DOE. See generally Department of Energy Gasoline Allocation Program: Hearings Before the Permanent Subcomm. on Investigations of the Senate Comm. on Governmental Affairs, 96th Cong., 2d Sess. (1980); see also Madison, OHA's Goldstein: A Bureaucratic Mastermind, Legal Times of Wash., July 9, 1979, at 5, col. 1; Burdick, Obscure, Bristly Energy Official: A Power Center, Legal Times of Wash., July 31, 1978, at 1, col. 2.

52. See generally Jones, Government Price Controls and Inflation: A Prognosis Based On the Impact of Controls in the Regulated Industries, 65 CoRNELL L. REv. 303 (1980).

53. Civil Aeronautics Act of 1938, 49 U.S.C. $\$ 1324$ (1976).

54. Communications Act of 1934, 47 U.S.C. $\$ 151$ (1976).

55. Natural Gas Act of 1938, 15 U.S.C. $\$ 717$ (1976); Federal Power Act of 1920, 16 U.S.C. $\S 792$ (1976).

56. Securities Exchange Act of 1934, 15 U.S.C. \& 78d (1976).

57. Interstate Commerce Act of 1887, 49 U.S.C. $\$ 11$ (1976); Hepburn Act of 1906, 49 U.S.C. $\S 1$ (1976); Motor Carrier Act of 1935, 49 U.S.C. $\S 304$ (1976).

58. See Jones, supra note 52, at 313-18. 
for the welfare of consumers, but for the welfare of the regulated industries as well..$^{59}$

Recent regulatory programs are more diffuse. Problems-such as health, safety, and the environment - are perceived not on an industryby-mdustry basis, but on a societal or even global basis. These broad problems often elicit governmental action that cuts across industry lines as well as state, national, and international boundaries. Although some industries are more likely than others to create safety, health, or environmental problems, these problems are not industry-specific. Moreover, certain economic regulation, such as the price and allocation controls imposed on the petroleum industry for ten years and those presently in effect in the natural gas industry, applies to so diverse a group that atteinpts to establish sensible industry-wide regulation inevitably meets with a variety of "bad-fit" problems. Economic regulation of this sort seeks to replace the market, not simply to solve specific inarket failures. The inagnitude of such regulatory tasks, in the economic as well as in the health, safety, and environmental splieres, is enormous. Much of this regulation has required such an elaborate system of rules, regulations, and bureaucracy that it approaclies a form of "supergovernment."

When Congress enacts statutes and erects bureaucracies to regulate many industries, the responsibilities of tle agencies grow broader and more complex. Agencies face the dilemma of devising rules specific enough to be meaningful, yet general enough to fit a variety of situations. The broader the regulatory task, the greater the likelihood that unforeseen situations will arise and thus, the greater the need for regulatory fine-tuning. Apart from the complexity that arises froin the diversity and breadth of the industries to which the regulations apply, there are also enormous substantive and interpretive difficulties. Ignorance compounds complexity when agencies must deal witl such issues as the long-run effects of low-level radiation, cost-benefit calculations involving the value of a human life, or the "appropriate" regulated price for a nonrenewable fossil fuel. The complexity of these issues creates a need to experiment on a case-by-case basis, particularly wlien the agency is entrusted with a regulatory task that, in truth, no one knows a great deal about. Adopting a general rule followed by a series of exceptions that fine tune and sliape the rule as nore knowledge is acquired may be the nost sensible way to carry out an extraordinarily difficult regulatory task. ${ }^{60}$

59. See authorities cited at note 209 infra.

60. See, e.g., 29 U.S.C. $§ 655$ (b)(5) (1976) (OSHA regulation of toxic substances). What is and what is not carcinogenic is by no means easy to determine. See also Currie, Rulemaking 
Other reasons that increase the need for active exceptions processes include the abandonment, in soine areas, of traditional New Deal approaches to the delegation of legislative power and a related decline in the deference accorded agency expertise in general. The New Deal approach to regulation usually has been characterized by broad, often nebulous delegations of legislative power which represent the end result of the political bargaining process. These broad delegations are usually coupled with heavy congressional rehance on agency expertise. ${ }^{61}$ A decline in trust in the wisdorn of government in general and in the efficacy of bureaucracy in particular, as well as an overall perception of governmental failure inay, in part, account for the decrease in broad delegations of authority to agencies; however, there are a number of inore tangible factors that inake administrative action suspect. Inflation has made the cost of regulation increasingly apparent, particularly in the 1980 's, an era characterized by a "Great Inflation" rather than a "Great Depression."62 In soine cases, as in controlling the price of oil, the international dimensions of the problein make effective regulation impossible. ${ }^{63}$ In addition, teclinological change inay necessitate new regulatory approaches. ${ }^{64}$ Most importantly, there is growing recognition that inany fundainental agency decisions are not capable of scientific precision, but are inherently political in nature. ${ }^{65}$ This realization has helped undermine the aura of expertise surrounding agency decisionmaking. ${ }^{66}$

Under the Illinois Pollution Law, 42 U. CHI. L. REv. 457, 480-85 (1975). Moreover, it has taken OSHA a remarkably long time to promulgate rules in this area. But see notes 169-75 infro and accompanying text for the procedural problems this approach can lead to if used to excess.

61. See Stewart, The Reformation of American Administrative Law, 88 HARv. L. REv. 1667, 1676-81 (1975).

62. Address by A. E. Kahn, reprinted in ViJTiEnde VlaAms WeTENSchappeluK Econ. Cong. 11, 18-21 (April 8-May 9, 1981).

63. There are no easy solutions to problems such as "cleaning up our rivers and air" because increasingly we are dealing with problems that are international in scope and beyond any regulator's power, no matter how we structure the solution. For example, oil price controls failed to fully control the price of oil because over $40 \%$ of oil used in the United States came from beyond our borders. The international scope of regulatory problems diminishes agency control of an issue and, consequently, the ability of an agency to please at least some constituencies.

64. For example, the ability to transmit electricity long distances without significant loss of energy makes for greater competition at the generation stage and raises the possibility of deregulation of this aspect of the eleetric utility industry. See Essay, Efficiency and Competition in the Electric-Power Industry, 88 YALE L.J. 1511, 1511-14 (1979).

65. See Industrial Union Dep't v. American Petroleum Inst., 448 U.S. 607, 671-88 (1980) (Rehnquist, J., concurring); Ackerman \& Hassler, Beyond the New Deal: Coal and the Clean Air $A c t, 89$ YALE L.J. 1466 (1980).

66. See generally, Industrial Uinon Dep't v. American Petroleum Inst., 448 U.S. at 721-23 (1980) (Marshall, J., dissenting); 45 Fed. Reg. 5002 (1980) (OSHA formal policy for regulating carcinogeus); R. SMith, The Occupational SaFetY AND Health Act 59-71 (1976); Aman, supro note 14, at 526-32; Berger \& Riskin, Economic and Technological Feasibility in Regulating 
As a result of perceived deficiencies in the regulatory arena, Congress has recently tried to control or check bureaucracy where possible, to abolish it where appropriate, and to reform it where necessary. One method of congressional control over regulation is to make more specific delegations of legislative power. There is soine evidence, particularly in the energy and environmental fields, that Congress is adopting a stricter approach to delegation. The Natural Gas Policy Act of $1978,{ }^{67}$ for example, rejects the "just and reasonable" formula of gasrate regulation set forth in the 1938 Natural Gas Act. ${ }^{68}$ Instead, it favors legislatively setting the maximum prices for natural gas over a seven-year period with certain adjustments. ${ }^{69}$ Similarly, the Natural Gas Policy Act sets forth certain curtailment priorities for future natural gas shortages. ${ }^{70}$ This contrasts with the 1938 Natural Gas Act that simply directed the Federal Power Commission to set "just and reasonable rates" and, by implication, to develop reasonable curtailment plans if necessary. ${ }^{71}$ The Clean Air Act Amendments of 1977 also provide for a more substantive role for Congress. ${ }^{72}$ Such statutory provisions rival in complexity and detail the rules and regulations promulgated by the agency that carries out these regulatory tasks.

Though increased congressional involvement may represent a more responsible legislative approach, it can create enormous implementation problems. Specific statutes as well as specific rules generate the need for exceptions. Specific statutes make exceptions processes especially necessary because it is much more difficult to amend a statute than to repeal or replace a rule. ${ }^{73}$

Toxic Substances Under the Occupational Safcty and Health Act, 7 EcoLOGY L.Q. 285; Pederson, Formal Records and Informal Rulemaking, 85 Y ALE L.J. 38 (1975); Stewart, Paradoxes of Liberty, Integrity and Fraternity: The Collective Nature of Environmental Quality and Judicial Review of Administrative Action, 7 ENvTL. L. 463, 469-72 (1977).

67. 15 U.S.C. $\S \S 3301-3432$ (Supp. IV 1980).

68. 15 U.S.C. $\S \S 717 \mathrm{c}-717 \mathrm{~d}(1976)$.

69. The Natural Gas Policy Act of 1978 has much more detailed pricing provisions than does the 1938 Natural Gas Act. See 15 U.S.C. $\S \S 3311-3320$ (Supp. IV 1980).

70. See 15 U.S.C. $\S \S 3391-3392$ (Supp. IV 1980).

71. See generally FPC v. Louisiana Power \& Light Co., 406 U.S. 621 (1972).

72. See Clean Air Act Ameudments of 1977, 42 U.S.C. $\$ \S 7401-7626$ (Supp. III 1979) (containing provisions such as section 7409(a)(1)(A) which directs the Administrator to "publish proposed regulations proscribing a national primary ambieni air quality standard and a national secondary ambient air quahity standard for each air pollutant for which air quality criteria have been issued prior to such date"). See generally Ackerman \& Hassler, supra note 65.

73. For example, the Powerplant and Indnstrial Fuel Use Act of 1978, 42 U.S.C. $\$ \S 8301$ 8483 (Supp. III 1979), partially repealed by Omnibus Budget Reconciliation Act of 1981, Pub. L. No. $97-35,95$ Stat. 357 , provides for exceptions to its mandate that powerplants shift from gas or oil to coal. Sections 8321-8322 (exemptions for new facilities) and 8351-8352 (exemptions for existing facilities) of this statute are very exphicit. These sections allow an exemption to the statutory requirement that powerplants use coal rather than natural gas or petroleum if: 
Another aspect of recent regulation creates an increased need for administrative equity. Though the need for administrative equity is not confined to what has been described above as "supergovernment," such regulatory regimes, in particular, require the flexibility that exceptions processes provide. Even a carefully drafted rule can suddenly become obsolete or appear unnecessarily harsh if the conditions that gave rise to it significantly change. Gas allocation rules promulgated at a time of acute shortage may not be appropriate at a time of relative abundance. Even when a wholesale change in the rules or outright deregulation may be in order, exceptions processes permit a less drastic, yet effective, short-run regulatory response. For broad regulation to work effectively, it must often adopt not only substantive market-oriented approaches, but certain procedural aspects of the inarket as well, including the ability to shift gears quickly as circumstances demand.

Some may argue that certam areas of the common law are dead, ${ }^{74}$ but the need for common law case-by-case decisionmaking lives on. However, if exceptions to rules are freely and easily granted, with little or no regard for principle, the "inner morality of law" may be jeopardized. ${ }^{75}$ Exceptions may not only swallow rules but may leave little or no coherent pohicy or common law rule in their place. In extreine cases, such processes may result in a patternless collection of cases that grant or deny privileges on an arbitrary basis. Ironically, an arbitrary exceptions regime would be characterized not by too inuch law, but by no law at all. ${ }^{76}$ Thus, it is important to explore the scope of administrative exceptions processes to determine whether that scope is limited by definable equitable principles or nornns.

despite diligent good faith efforts:

(1) it is likely that an adequate and reliable supply of coal or other alternate fuel of the quality necessary to conform with design and operational requirements for use as a primary energy source, will not be available to such powerplant or installation at a cost (taking into account associated facilities for the transportation and use of such fuel) which, based upon the best practicable estimates, does not substiantially exceed the cost, as determined by rule by the Secretary, of using imported petroleum as a primary energy source;

(2) one or more site limitations exist which would [not] permit the operation of such a powerplant or installation using coal or any other alternate fuel as a primiary energy source; or

(3) the prohibitions of sections 8311 or 8312 of this title could not be satisfied without violating applicable environmental requirements.

Id. § 8321(a); see id. § 8351(a).

74. As Professor Gilmore observed, "we are told that Contract, like God, is dead. And so it is. Indeed the poimt is hardly worth arguing anymore." G. GILMORE, THE DEATH OF CONTRACT 3 (1974).

75. L. Fuller, The Morality of Law 38-40 (rev. ed. 1969).

76. Id. 


\section{The Exceptions Process}

Exceptions to administrative rules need not be granted or denied on a random basis, nor is the scope of exceptions processes necessarily without limits. For the most part, exceptions are limited not only by the usually vague statutes that authorize them, ${ }^{77}$ but also by certain definable equitable principles and the norms that underlie those principles. The purposes of this section are: (1) to identify various categories of exceptions; (2) to discuss the equitable maxims and norms that underlie these categories; and (3) to suggest the contours of these exceptions by assessing their containability and their fundamental goals.

\section{A. General Categories of Exceptions.}

Three broad categories of exceptions relief einerge. These are hardship exceptions, fairness exceptions, and policy exceptions. Hardship exceptions focus primarily on the individual characteristics of the particular petitioner and, to a large extent, most decisions to grant or deny such exception requests turn on facts peculiar to the petitioner. Fairness exceptions also focus on the pecular plight of the individual petitioner, but particularly on the petitioner's relationship to the regulatory goals of the program and on the comparative impact that program has on similarly situated regulated entities. The fairness and reasonableness that determine the fairness exceptions infuse the regulatory system with an unwritten "constitution." Policy exceptions, on the other hand, are less concerned with the plight of the individual petitioner and focus primarily on the overall goals of the regulatory program. The petitioner's regulatory burden is neither unique nor particularly severe compared to other regulated entities. Policy exceptions often allow the agency to implement a new or refined policy on an experimental basis.

Policy exceptions are not based primarily on the need to modify a general rule in light of particular circumstances. They are not, therefore, truly equitable exceptions. Nevertheless, all three categories of exceptions often overlap and should be examined together. Even purely equitable exceptions, for example, have policy ramifications. Moreover, a weak equitable case is often buttressed by a favorable policy result. Conversely, an unacceptable policy result may undermine a particularly strong equitable case. The overall goals and purposes of a regulatory program are a policy backdrop to virtually every exception decision, whether the decision is purely equitable, purely policy, or somewhere in between. In short, these general categories of exceptions

77. For a discussion of exception-creating statutes, see note 11 supra. 
are not necessarily mutually exclusive. In many cases various categories of exceptions may properly be invoked.

\section{B. Hardship Exceptions}

Exceptions may be granted because compliance with the rule in question would create a substantial hardship. There are four types of hardship exceptions: economic, technological, legal, and medical.

\section{Economic Hardship.}

Maxim: Equity will not allow the application of a particular regulation to force a firm out of business or to render a piece of property valueless unless the social benefits of coinpliance with that regulation outweigh the severe costs to the petitioner.

Economic-hardship exceptions are usually generated by such statutory criteria as "serious hardship," "special hardship," or similar terms. ${ }^{78}$ Such exceptions are not available, however, merely on an allegation that the costs of individual compliance are "severe" or "unreasonable." To establish a prima facie case for this exception, the petitioner must allege that the costs are so great that the economic viability of the firm or the value of a piece of property is in grave jeopardy. The petitioner must also show that the threatened shutdown or economic loss is caused by the regulation in question and that his circumstances are unique..$^{79}$

Zoning use variances provide the classic example of this kind of equitable exception. Courts have long required that before a use variance be granted, the record must show:

(1) [that] the land in question cannot yield a reasonable return if used only for a purpose allowed in that zone; (2) that the plight of the owner is due to unique circumstances and not the general conditions in the neighborhood which may reflect the unreasonableness of the zoning ordinance itself; and (3) that the use to be authorized by the variance will not alter the essential character of the locality. ${ }^{80}$

Similar formulations of the standards necessary to obtain an exception or variance are found in complex environmental and energy legislation. Rather than the value of a piece of property, however, the economic viability of a firm is in question. The economic plight of the firm must be unique and, just as zoning cases require that a variance

78. See note 84 infra.

79. In extreme cases, a taking claim based on the 14th amendment might also lie. See note 25 supra.

80. 3 R. ANDERSON, supra note 50, § 18:15 at 172, citing Otto v. Steinhilber, 282 N.Y. 71, 76, 24 N.E.2d $851-53,16$ N.Y.S.2d 71, 76 (1939). 
not seriously affect the overall character of the neighborhood, the proposed exception must not undercut the underlying policy goals of an environmental or energy statute. The costs of forcing a firm to shut down must exceed the overall regulatory benefits that compliance with the regulation would provide.

The Federal Water Pollution Control Act ${ }^{81}$ thus provides for variances from effluent limitations with respect to individual point sources on a showing that "such modified requirements (1) will represent the maximum use of technology within the economic capability of the owner or operator; and (2) will result in reasonable further progress toward elimination of the discharge of pollutants." 82 Similarly, the Natural Gas Policy Act of 1978 (NGPA) ${ }^{83}$ requires the Federal Energy Regulatory Commission (FERC) and other agencies that help implement natural gas price controls to establish procedures "for the making of such adjustments, consistent with the other purposes of this chapter as may be necessary to prevent special hardship, inequity, or an unfair distribution of burdens." 84

In administering the NGPA, the FERC has entertained several adjustment requests, including exceptions based on economic hardship. In the Penn-Dixie Steel Corp. ${ }^{85}$ application, for example, the petitioner sought interim and perinanent exception relief from the incremental pricing regulations published pursuant to Title II of the NGPA.86 These regulations required Penn-Dixie to pay a premiun price for the natural gas it used under its boilers. In granting interim exception relief to Penn-Dixie pending a full review of the inerits, the commission's order noted:

On April 7, 1980, Penn-Dixie Steel and its parent company, Penn-Dixie Industries, each filed petitions for reorganization under

81. 33 U.S.C. §§ 1251-1376 (1976 \& Supp. III 1979).

82. Id. $\S 1311(\mathrm{a})$-(c). The extent to which variances are authorized was argued in EPA v. National Crushed Stone Ass'n, 449 U.S. 64 (1980) ("best practicable control technology currently available" variance based on economic capability was not allowed under the Federal Water Pollution Control Act Amendments of 1972).

83. 15 U.S.C. $\S \S 3301-3432$ (Supp. IV 1980).

84. Id. $\$ 3412$ (c). $C f$. Federal Energy Administration Guidelines, 41 Fed. Reg. 50,856 (1976) (establishing "serious hardship criteria" for granting exceptions).

85. No. SA81-12-000, 14 F.E.R.C. I 62,098 (F.E.R.C. Jan. 30, 1981) (available April 2, 1982, on LEXIS, Genfed library, Energy file) (hereinafter cited No. SA81-12-000).

86. See 15 U.S.C. $\$ 3341$ (Supp. IV 1980). Incremental pricing is an attempt to assign the cost of higher-priced new gas to particular users who Congress believes should be discouraged from using natural gas. Rather than rolling in the cost of the inore expensive gas and charging everyone a slightly higher average price, incremental pricing fixes the fuel cost of new or imported natural gas on certain classes of users. For a general discussion of this approach, see Aman \& Howard, Natural Gas and Utility Rate Reform: Taxation Through Ratemaking?, 28 HAstings L. REv. 1085, 1127-39 (1977). 
Chapter XI of the Federal Bankrupcy Code . . . Penn-Dixie Steel states that anticipated incremental pricing surcharges of approximately $\$ 400,000$ in 1981 will jeopardize both its planned return to profitability and its plans for reorganization. ${ }^{87}$

In Vertac Chemical Corp. ${ }^{88}$ the applicant was scheduled to be in bankrupcy proceedings when the increinental pricing provisions of the NGPA were to take effect. As the hearing examiner noted:

Vertac estimates that its inonthly gas costs will increase by $\$ 141,800$ due to incremental pricing. It asserts that this obligation, when coupled with certain environmental costs it claims inust be incurred, will cause the type of hardship requisite for relief. It claims that, due to competition from both foreign and domestic fertilizer manufacturers, it will be forced to absorb these increased costs rather than being able to pass them on to its customers . . . ${ }^{89}$

The hearing examiner concluded that:

[I]n view of the extreme financial distress that currently befalls Vertac, the existence of an ongoing Order of Discharge in Bankrupcy, and the level of incremental surcharges that the Commission Staff estimates might be incurred witlout relief, the Commission finds that a special hardship may result to Vertac without exemptive relief. ${ }^{90}$

A regulation may have an adverse impact on a particular firm because of the regulation's favorable impact on competitors of that firm. This adverse impact inay also produce economic hardship. In $\mathrm{New}$ England Petroleum Corp, ${ }^{91}$ (NEPCO), for exainple, the petitioner filed for exception relief from the Federal Energy Administration, a predecessor agency of the Department of Energy. ${ }^{92}$ NEPCO alleged that the

87. No. SA81-12-000, supra note 85. But see Alabama Gas Corp., No. SA80-37, 10 F.E.R.C. I 62,109 (F.E.R.C. Feb. 8, 1980) (available April 2, 1982, on LEXIS, Genfed library, Energy file) (petitioner unsuccessfully argued that incremental pricing regulations would allow underbidding by alternative fuel suppliers, resulting in economic hardship. The presiding officer denied the exception request, noting that the harm was speculative, not actual).

88. No. SA80-62, 12 F.E.R.C. I 61,234 (F.E.R.C. Aug. 29, 1980) (available April 2, 1982, on LEXIS, Genfed Library, Energy file).

89. Id. LEXIS at 5-6.

90. Id. See also American Petrofina Co., No. SA 80-90, 13 F.E.R.C. 162,151 (F.E.R.C. Nov. 10, 1980) (available April 2, 1982, on LEXIS, Genfed hbrary, Energy file) (at Americana's current contract price the installation of compression and dehydration facilities would have resulted in special hardship to Americana. Consequently, the hearing examiner granted Americana's request for an exemption from the rules mandating a inaximum price level for the kind of contractual arrangement Americana had).

91. [1975-1976 Transfer Binder] ENERGY MGMT. (CCH) (3 FEA) I 83,015 (Nov. 17, 1975).

92. The Federal Energy Administration was created in 1974 and had exclusive control of the oil price and allocation program authorized by Congress in 1973 in the Emergency Petroleum Allocation Act. See 15 U.S.C. $\$ \$ 761-786$ (1976). When the Department of Energy was created, FEA was absorbed into it. Exceptions and other adjustment requests were handled by the Office of Hearings and Appeals, a part of the Department of Energy. For a coinplete discussion of the creation of these agencies, see Aman, supra note 14, at 491. 
implementation of the crude oil entitlements program ${ }^{93}$ was much more beneficial to one of its competitors than to it. NEPCO proved that it faced serious economic difficulties and could not effectively compete without exception rehef. Its refinery operations had become unprofitable, and a strong possibility existed that it would be forced to terminate its activities in the residual fuel oil market if the exception relief sought were not granted.94 Specifically, NEPCO asked for additional entitlements on its imports of residual fuel oil se that it could remain a viable competitor in this market. The Administrator granted the requested relief, reasoning that:

NEPCO has played an important role in the highly concentrated East Coast residual fuel oil inarket and has been a strong, independent competitor in that market for some time. The elimination of NEPCO from its historic position would certainly have a significant adverse impact on the structure of the residual fuel oil market in the eastern United States and would tend to frustrate the Congressional objectives relating to competition in the petroleun industry set forth in the Emergency Petroleum Allocation Act of 1973 and the Federal Energy Administration Act of 1974.95

Thus, exception relief not only kept NEPCO solvent, but was in accord with the more general regulatory goals of the program-to encourage a diverse and competitive market structure.96 Notimg the difficulty of ascertaining the future of the regulatory program, the

93. The entitlements program was developed pursuant to the Emergency Petroleum Allocation Act of 1973, see note 14 supra. The program was extremely complicated, but its overall goal was simple: to ensure that all refiners imcurred the same average crude oil cost. The program provided for entitlements allotted to refiners on a monthly basis. The entitlements were to be determined as follows:

[E] ach [refiner] receives a number of entitlements equal to the number of barrels of price controlled oil it would run if the percentage of controlled oil in its total crude oil mput were the same as the national average. If the percentage of controlled oil exceeds the national average, the refiner must purcliase additional entitlements from some other refiner whicls was given more entitlements than needed for the amount of controlled oil in its refinery runs.

Senate Comm. on Gov't AfF., 95th Cong., 2d Sess., Study on Federal Regulation 733, 753 (Comm. Print 1978).

94. [1975-1976 Transfer Binder] ENERGY MGMT. (CCH) (3 FEA) đ 83,015 at 83,052-53. Specifically, NEPCO alleged that:

[B]ecause its refinery operations have become extremely unprofitable, it has increased its purchase of residual fuel oil on the spot market in order to fulfill its customers' need for the product and naintain its position in the market. However, this departure from the firm's norinal busimess pattern has exacerbated the firm's cash flow difficulties since purchases of refined products are typically made on 15 or 30 day credit terms, while NEPCO's purcliases of crude oil are generally made on 60 or 90 day credit terms.

The casls flow data whicl NEPCO has provided indicates that NEPCO's cash obhgations will substantially exceed its anticipated cash receipts in the immediate future and the firm will have accrued a cash deficit of $\$ X X X X$ by mid-November.

Id. at 83,052 .

95. Id.

96. See note 93 supra. 
Commissioner added that the firm should not be sacrificed for what could be a temporary regulatory program. ${ }^{97}$

\section{Technological Hardship.}

Maxim: Equity will not require a firm to shut down when failure to comply with a regulation arises from technological incapability, and the costs of a shutdown outweigh the social benefits that would otherwise result.

Exceptions that arise because the regulatory goal is beyond the technological capability of the firm, regardless of cost, constitute technological-hardship exceptions. They can be generated by statutes and criteria similar to those authorizing economic-hardship exceptions. ${ }^{98}$ Some statutes deal specifically, however, with technological capability. 99 Actions that are technologically impossible because they are beyond the economic means of a particular firm may be treated as

97. [1975-1976 Transfer Binder] ENeRgY MGMT. (CCH) (3 FEA) If 83,015, at 83, 052-53 (Nov. 17, 1975). President Reagan lifted all controls on January 28, 1981. See Exec. Order No. 12,287, 44 Fed. Reg. 9909 (1981). President Carter had begun to phase out the controls on a gradual basis beginning June 1, 1979. See, e.g., Exec. Order No. 12,153, 44 Fed. Reg. 48,949 (1979) (decontrol of heavy oil).

98. See, e.g., ILL. ANN. StaT. ch. 1111/2, § 1035 (Smith-Hurd West Supp. 1981-82), which provides:

To the exteut consistent with applicable provisions of the Federal Water Pollution Con-

trol Act Amendments [and other federal law] the Board may grant imdividual variances

... whenever it is found, upon presentation of adequate proof that compliance with any

rule or regulation, requirement or order of the Board would impose an arbitrary or un-

reasonable hardship.

Id. (emphasis added). As the discussion of the Lindgren case, text accompanying notes 91-96 infra, indicates, this geueral hardship statute can apply to both technological and economic impossibility.

99. See, e.g., Clean Air Act Amendments of 1970, 42 U.S.C. $§ 7521$ (b)(5)(c) (Supp. III 1979). Four requirements are set forth:

(i) such waiver is essential to the public interest . . . (ii) all good-faith efforts have been inade to meet the standards ...., (iii) the applicant has established that . . . technology [is] not available ...., and (iv) studies and investigations of the National Academy of Sciences, . . . have not indicated that technology, processes, or other alternatives are available . . . to meet such standards.

Id.

Of course, some standards are "technology-forcing" standards-they are not now technologically feasible, but they set future goals. Companies that are ultimately able to meet these goals are considered capable of complying with these standards. See Union Elec. Co. v. EPA, 427 U.S. 246, 266-68 (1976) (claim of economic or technological hardship cannot be used to reject state impleinentation plans that are inore stringent than federal law because, iu part, there are opportunities in the regulatory process to consider such problems, such as requests for variances or for delayed compliance); Henderson \& Pearson, Implementing Federal Environmental Policies: The Limits of Aspirational Commands, 78 Colum. L. Rev, 1429, 1445-53 (1978). As one commentator has noted, however, a provision allowing exceptions based on technological incapability alone:

provides an absolute entitlement to a variance to anyone who needs more time, without regard to the extent of his loss if required to shut down or to the extent of harm being caused to his employees. It is entirely conceivable that in some cases the loss inay be so small and the hazard so great that interim shutdown should be required. Variances 
economic-hardship exceptions. These two types of hardship exceptions are closely related.

In EPA v. Lindgren Foundry Co. ${ }^{100}$ the Lindgren Coinpany requested a variance to emit pollution in excess of that allowable by state regulations for seven inonths while the coinpany installed the equipment necessary to deal with the problein. ${ }^{101}$ If the foundry had coinplied with the regulations during the seven-month period, it would have gone out of business, and, as undisputed evidence slowed, never reopened. ${ }^{102}$ Thus, along with a claim of technological liardship, the company advanced a derivative claim of economic hardship.

The evidence showed that if the plant were to close perinanently, not ouly would the owners lose their investinent, but nearly one hundred employees might liave to seek new jobs. ${ }^{103}$ At the same time, the pollution was manifestly causing imjury in the community. Comments from the public mcluded:

"It tracks in on my carpet. It is all over the window sills. It is the type of dirt that you cannot clean unless you get a cleaner on a cloth. . .." "I washed out a white blouse and hung it out on the line ... and when I went out to get it, it was completely covered. . . ." "I could not sit out in my back lawn when this smoke would come across . . . . You would be sitting there, and all of a sudden, you would look down, and you are covered with soot . . . ."104

The Illinois Pollution Board deried the variance because the owners had not overcome the heavy presunption against granting variances and had not presented hard evidence of economic injury. The board reasoned:

The hardships to the creditors and to Lindgren's former einployees are substantial and regrettable, but they are not so great as to make it arbitrary to insist that Lindgren refrain froin making miserable everyone in its vicinity . . . . The benefit from comphance will be very substantial, and it is by no means dwarfed by the concomitant cost. ${ }^{105}$

should depend, as they commonly do in pollution statutes, upon a showing that immediate coinphance would result in unreasonable hardship.

Currie, OSHA, 1976 AM. B. Found. RESEARCH J. 1107, 1152 (1976).

100. 1 Ill. P.C.B. 11 (1970), discussed in Currie, Enforcement Under the Illinois Pollution Law, 70 Nw. U.L. REv. 389, 412-15 (1975).

101. See Currie, supra note $\mathrm{I00}$, at 413 . In this sense, a request for a temporary variance is also a request for delayed comphance. The injunction is not intended to be permanent, but while in existence it is intended to exonerate the petitioner from any sanctions for violation of the rule.

102. See id.

103. Id.

104. Id. 413-14 (quoting EPA v. Lindgren Foundry Co., 1 Ill. P.C.B. at 21).

105. Id. 414 (quoting EPA v. Lindgren Foundry Co., 1 Ill. P.C.B. at 22). 
Professor Currie has surmised that the board may have been predisposed against the foundry because the owners had reason to know when they purchased the foundry that the board would require thein to follow the regulation or obtain a variance. ${ }^{106} \mathrm{~A}$ dissenter agreed that a variance requires the petitioner's injury to be significantly greater than the benefits to the community but found this standard met in the present case:

There is no question that the community surrounding Lindgren will suffer some degree of harm . . . for seven months .... . [But this period coincides with] the colder season when outdoor recreational enjoyment would not be as severely uffected. Weighed agaimst the hardships imposed upon the present owners of Lindgren, the employees of Lindgren, the creditors of Limdgren, and the commumity at large, such harm seems small imdeed. ${ }^{107}$

\section{Legal Hardship.}

Maxim: Equity does not require compliance with a rule or regulation when such compliance necessitates breaking another valid rule or regulation.

Given the complicated maze of safety, environmental, health, and economic regulations, it is entirely conceivable that actions required by one agency are prohibited by the regulations of another. ${ }^{108}$ Forcing a firm to break the law of one agency to comply with a particular rule of that or another agency gives rise to a legal-hardship exception.

In Schenley Distillers, Inc. ${ }^{109}$ for example, Schenley sought an adjustment froin section 401 of the Natural Gas Policy Act, which prohibited Schenley, in the event of a natural gas shortage, from using natural gas as a boiler fuel if it had the technological capacity to use coal instead. Schenley sought this adjustment because "its Lawrenceburg plant was not legally authorized to burn coal in place of natural gas, despite the intermittent ability to do so during the years 1975 through 1978." 110 The Commission granted the exception:

106. $I d$.

107. Id. 414 (quoting EPA v. Lindgren Foundry Co., 1 Ill. P.C.B. at 28). For a case in which this kind of variance was granted, see Ozark-Mahoning Co. v. EPA., 1 Ill. P.C.B. 121 (1970), cited and discussed in Currie, supra note 100, at 414-15.

108. See, e.g., Complaint at 1, Sears, Roebuck \& Co. v. Attorney General, 19 Fair Empl. Prac. Cas. (BNA) 916 (D.D.C. 1979) (complaint on file at Duke University Law Library). The complaint alleged, inter alia, that "Sears and the plaintiff class are faced with conflicting coinpliance requirements which result in discrimination against all einployees, are subjected to loss of property, and are denied a diverse workforce . ..."

109. No. SA80-75, 12 F.E.R.C. \ 62,172 (F.E.R.C. Aug. 27, 1980) (available April 2, 1982, on LEXIS, Genfed library, Energy file).

110. Id., LEXIS at 2. 
Because Schenley's use of the coal-fired boilers is so circumscribed by the Pollution Control Board, Schenley cannot be considered to have the installed capability to burn coal lawfully, within the meaning of $\$ 273$ of the Energy Security Act. For the same reason, Schenley cannot be considered to have the ability to use coal as an alternative fuel, within the meaning of Commission Order Nos. 55 and 55-B. It would be inequitable to deny the essential agricultural priority to Schenley's Lawrenceburg plant when other essential agricultural users without alternative fuel capability have been accorded that priority .... The exemption will be conditioned, however, such that the exemption will not be available during those times when Schenley is lawfully permitted to burn coal ....111

\section{Medical Hardship.}

Maxim: Equity does not require comphiance with a rule or regulation when such coinphiance would seriously affect the health of the coinplying petitioner.

There are very few instances in which a specific rule creates a personal danger for the regulated; however, a number of such examples have arisen from energy regulation. The mandate that the temperature must be kept at certam inaximum levels in the summer and minimum levels in the winter in federal buildings ${ }^{112}$ spawned several health-related exceptions. The Department of Energy granted an exception to the inaximum-temperature regulation to a petitioner who showed that failure to keep his office between sixty-eight and seventy degrees Farenheit would exacerbate his optic neuritis, thus creatimg temporary loss of vision. ${ }^{113}$ The order noted:

111. Id., LEXIS at 6-7 (footnote omitted).

112. 10 C.F.R. $\S 490$ (1981).

113. Joseph F. Troy [1979 Transfer Binder] ENERGY MGMT. (CCH) (4 DOE) đ 81,125 (Sept. 7, 1979). See also Commodities Exchange Center, Inc., [1980 Transfer Binder] ENERGY MGMT. (CCH) (5 DOE) I 81,315 (May 9, 1980) (exception denied to company that provides facilities for trading of commodity futures because no specific nedical conditions detailed that would be caused or aggravated by $78^{\circ} \mathrm{F}$. temperature-"evidence of headaches alone [does not] constitute the type of serious health risk which would warrant the approval of exception rehef'); Washington Univ. [1980 Transfer Binder] ENERGY MGMT. (CCH) (5 DOE) If 81,084 (Feb. 20, 1980) (exception to winter restrictions denied because no health risk to nude models shown-personal discomfort alone not sufficient to warrant exception); Larry Flint Publications, Inc. [1979 Transfer Binder] ENERGY MGMT. (CCH) (4 DOE) If 81,243 (Dec. 18, 1979) (exception to teinperature maximum because "Larry Flint, the chief executive of Flint, is partially paralyzed and must operate out of a wheel chair"); Community Interfaith Services, Inc. [1979 Transfer Binder] ENERGY MGMT. (CCH) (4 DOE) If 81,228 (Dec. 12, 1979) (exception denied even though petitioner claimed the maximun temperature requirements made it impossible to continue its instruction in "altered states of consciousness"); Hammermill Paper Co. [1979 Transfer Binder] ENERGY MGMT. (CCH) (4 DOE) ๆ 81,165 (Oct. 23, 1979) (exception denied to lower temperature in "lunoceupied" buildings at night because no health probleni or inordinate increase in difficulty of completing work shown in night inaintenance workers); Disabled American Veterans, [1979 Transfer Binder] ENERGY MGMT. (CCH) (4 DOE) I] 81,116 (Aug. 16, 1979) (exception granted to Disabled Ameri- 
Many of the exception requests . . . received in this area are based on an applicant's allegations that as a result of his medical condition, lie will experience serious medieal consequences unless the DOE modifies the temperature levels at which his working environment may be maintained .... [A] panel of physieians on the staffs of the National Institutes of Health has been formed. These physicians advise the Office of Hearings and Appeals whether the temperature level ... could reasonably be expected to exacerbate the particular medical condition set forth in the petitioner's submission. ${ }^{114}$

\section{Analysis of Hardship Exceptions.}

As noted above, 115 the random, unprincipled granting of exceptions could easily undermine a regulatory scheme. An examination of hardship exceptions, however, reveals that they are "contamable," that is, capable of rational apphication to a reasonably defined set of cases, and that they serve the underlying purposes of the regulatory regime to which they apply. Moreover, underlying a regulatory system's need for hardship exceptions are two fundamental norins: econo1mic survival, often expressed as a desire for stability and competition within an industry; and the philosophical proposition that for a rule to be legitimate, "ought implies can."116

Economic extinction sets the outernost limit on the imposition of individual regulatory costs to achieve general policy goals. Though Congress may have decided that imdustries should internalize certain environmental costs or remit windfall profits, Congress's broad legislative objectives do not automatically outweigh the contmued survival of regulated firms. The regulatory cures for environmental pollution or exorbitant prices should not necessarily cripple the imdustries to which

can Veterans in order to relieve amputees of severe discomfort they experience at $78^{\circ} \mathrm{F}$.). Community Interfaith Services, Inc., [1979 Transfer Binder] ENERGY MGMT (CCH) (4 DOE) ๆ 81,228 (Dec. 12, 1979) (exception denied even though petitioner claimed the maximum temperature requirenents inade it impossible to continue its instruction in "altered states of consciousness").

In Community Interfaith, the petitioner argued that compliance would result in financial diffculties. Moreover, a leading doctor stated "inordinate heat or cold or even a draft would interfere with or prevent the lypnosis process." Nevertheless, exception relief was denied. The order distinguished the case from other medical-hardship cases, noting that the relief was requested for healthy individuals in non-work-related activity. Petitioner failed to show that the affected individuals' discomfort or reduced level of participation would be any greater than that of thousands of other participants in social, cultural, and recreational activities throughout the nation. The cases discussed above also have an economic hardship aspect-impaired busmess resulting from temperature restrictions.

114. Joseph F. Troy, [1979 Transfer Binder] ENERGY MGMT. (CCH) (4 DOE) I 81,125, at 83,018 (Sept. 7, 1979).

115. Sce text accompanying note 75 supra.

116. See R.M. HARE, FREEDOM AND REASON 51-66 (1963). 
they apply. Stability and preservation of economic order go hand in hand with environmental or economic reforms. The regulatory preference for individual firm survival does not necessarily mean that shutdowns must always be avoided, but such extreme consequences should be the result of a considered process, not the unintended or unconscious fallout of an overbroad statute or rule. ${ }^{117}$

Closely related to the norm of economic survival is the proposition that "ought imphies can." Enforcing legal rules against those who cannot comply creates the risk of undermining the legitmiacy of a regulatory program as well as the "inner morality of the law."118 Thus, if a regulated entity undertakes good-faith efforts to minimize the impact of alleged violations of a rule that it cannot coinply with, failure to consider an exception may raise questions of program legitimacy, unnecessary harshness, or gratuitous regulatory costs.

Similarly, the norm that there are soine costs that a rule cannot exact, even if those costs can be paid, underlies legal- and medicalhardship exceptions. Violating the law or doimg serious medical harm to oneself is beyond the demands of a legitimate systein of law. The former undermines the rule of law; the latter violates one's physical integrity. Solutions for social problems should not exact such extreme mdividual costs. Given the fundamental norms of econonnic survivalthat the law should mandate only what is possible and should respect physical human limitations - an active and primcipled equitable process is an essential part of any regulatory scheme.

The problem of containing the decisions that equitable processes generate does not necessarily undercut the usefulness and imiportance of such processes; hardship exceptions need not swallow the rules that necessitate thein. Given the extreme nature of the prima facie case that must be alleged before one is eligible for a hardship exception, sucl1 rehef can be confined to a relatively sinall class of cases. ${ }^{119}$ Hardship exceptions claims are susceptible to reasonably objective criteria-balance sheets that show serious cash-flow problems, a record that indicates the lack of a particular technology, conflicting legal rules, or documented inedical problems. The inherent problein of determining the primary cause of a firm's financial troubles in economic-hardship cases, and the complexity of balancing extreme individual costs with

117. Economic regulation often results in serious economic harm, yet challengers of such regulation will rarely be able to state a constitutional taking claim. Economic hardship exceptions are particularly relevant to this subconstitutional strata of cases. See note 25 supra.

118. See L. Fuller, supra note 75 , at 70-79.

119. See note 84 supra. See generally Comment, Variance Law in New York: An Examination and Proposal, 44 AlB. L. Rev. 781 (1981). 
anticipated social benefits, however, can make these decisions very difficult.

Determining causation in hardship cases is the inost serious difficulty. Causation in administrative equity cases is similar to the concept of standing. Before the administrator can consider the rehef sought by the petitioner, the petitioner inust demonstrate that his "phght" is caused by the particular regulations from which he seeks an exception.120 Granting exception rehef without careful scrutiny of the real causes of a firm's difficulties can easily result in an economic welfare prograin for the inefficient and unimaginative. ${ }^{121}$ To the extent that causation is treated lightly in exceptions cases, the scope of the exceptions process expands proportionately. If, on the other hand, proof of causation is rigorously deinanded, the actual differences among firms in their ability to absorb the costs of regulation are maintained. ${ }^{122}$ The end result is a inuch narrower exceptions process. ${ }^{123}$

120. See, e.g., the Federal Energy Administration's guidelines on causation, 41 Fed. Reg. 50,856-57 (1976):

The exceptions process is not intended as a panacea for every conceivable type of financial problem encountered by any firm doing business in the petroleum industry. Rather, exception relief is designed to alleviate specific operating difficulties which have arisen as a direct result of the application to a firm of a partieular regulatory requirement from which relief is sought.

Id.

121. Some commentators have suggested that the distributional consequences of regulations vary within and among industries. Soine firms are better able to absorb regulatory costs than others and thus might not strenuously oppose regulation. Indeed, the costs imposed may be much more difficult for such a firm's less efficient competitors to internalize, thereby giving them an added competitive edge. See generally R. LEONE \& J. JACKsON, The Political Economy of Federal Regulatory Activity: The Case of Water Pollution Controls in Studies IN PUblic Regulation 231-68 (Gary Fromm ed. 1981).

122. Policy exceptions are often of great importance to large, efficient firms that are the victims of unreasonably applied rules, and that are too stable to claim economic hardship. See text accompanying notes $156-95$ infra.

123. Marathon Oil Co. v. DOE, 482 F. Supp. 651 (D.D.C. 1979) (somctimes referred to as the "Ashland Oil case"-Ashland Oil being an intervenor) illustrates the substantive impact that an expansive approacli to causation can have. The rehef Ashland Oil sought froin the agency - an increase in its domestic supplies of oil to offset its loss arising from the Iranian cutoff-had to be provided by Ashland's own competitors. These competitors, including Marathon Oil Co., viewed Ashland's predicament differently. Apart from the evidence concerning Ashland's financial condition and the impact the Iramian embargo had on it, Marathon Oil Co. and the other plaintiffs argued that this was not the kind of problem that DOE regulations were intended to correct. They contended that "the real cause of Ashland's problems-and that of its customers-is that coinpany's discretionary business decision not to maintain worldwide crude oil operations, that is, to fail to develop secure sources of supply, but to rely instead upon the crude oil supplies of Iran." Id. at 655 (emphasis added). In short, the plaintiffs argued that "Ashland, not its competitors, must bear the consequences"' and that sucli circumstances did not warrant exception rehef. Id.

The court rejected these arguments, finding that the presidential proclamation barring oil importation from Iran was part of the regulatory prograni involved and thus the cause of Ashland's plight. Id. at 654-55. The court also noted that "It]he chaotic events of the last few weeks 
Balancing the costs of a shutdown with the social benefits likely to result from coinpliance is by no means an easy task. ${ }^{124}$ How this balance is struck depends, im part, on the nature of the regulatory program. Concerning health, safety, and environmental regulation, a shutdown, however costly, tends to further the primary policy goals of the regulatory scheme; a variance results in more pollution and arguably less safety than might otherwise exist. In economic regulations such as natural gas or oil price and allocation controls, however, a shutdown is more likely to undercut some regulatory goals while bolstering others. For example, oil price controls sought not only to deprive producers of windfall profits on "old" oil, but also to encourage greater production of "new" oil, thereby decreasing our dependence on foreign oil. ${ }^{125}$ The goal of reducing foreign imports of oil is clearly undercut if a well has to be closed because it can no longer profitably produce "old" oil at the controlled price. An exception that allows a higher price to be charged so that the well can remain in production furthers

. . were apparently not foreseen by anyone, including the government of the United States." Id. at 655 . See text at notes 197-207 infra.

The ambiguity inherent in designating the precise causal link between the problem complained of and the regulation that consequently needs to be altered can, as the approach in Marathon indicates, greatly enhance the power of the administrative chaneellor. The liberal approach to causation taken by the DOE and affirmed by the court resulted in the imposition of agency power, and, in effect, regulatory power, in an area in which it arguably should not lave been exteuded. This approach can easily transform the exceptions process into a ineans for passing ad hoc legislation to deal with new problems, rather than allowing administrative equitable relief from rules already in existence. As such, the rehef it offers is similar to the Chrysler Corporation's petitioning the President to alleviate its economic woes. Though a strong argument can be made that Chrysler's problem is self-imposed, its economic phight may be comrected to the variety of regulatory programs that impose costs on the corporation. Chrysler thus sought government support and supervision as affirmative rehef. Equitable coneerns dictated such support and supervision as the solution to Chrysler's problems. This solution, however, is a substitute for market remedies; neither the Chrysler nor the Ashland case is an instance of equitable processes at work within a predefined regulatory framework. An equitable approach to the scope and purpose of an exceptions process cannot be justified on the ground that the present rules should not apply in certain cases; rather, it is justified on the ground that the rules should apply and should actually be expanded or amended to take into account an entirely new situation.

Thus, an agency's approach to causation in the context of exception relief can have a profound substantive impact on both the beneficiaries of the exeeption orders and the regulated entities that are consequently aggrieved by such rehef. A broad approach to causation can significantly expand an agency's regulatory jurisdiction and can radically change the agency's focus without benefit of a formal amendment to the rules involved and without benefit of rule-making processes.

124. See, e.g., EPA v. Lindgren Foundry Co., 1 Ill. P.C.B. 11 (1970), discussed in Currie, supra note 100 , at $412-15$.

125. Oil price controls distinguished between "old" and "new" oil. Old oil was oil discovered prior to the Arab embargo of 1973 and was to be sold at the relatively low price it sold for at that time. New oil was newly discovered oil. To encourage discovery, this oil could be priced substantially higher than old oil. For a summary of the oil price and allocation program, see TASK FORCE, supra note 14. 
the goal of greater domestic production, but undercuts the goal of equitable prices for consumers. Nevertheless, exception relief is more likely in price-control cases than in health or environmental cases. The imperceptible rise in the overall cost of oil to consumers that would result froin an exception is likely to be less harmful to that prograin's overall goals than the health and safety problems that could arise if more pollution were produced or less safety attained.

Despite the importance of hardship exceptions, they should be granted sparingly, particularly when health or environmental regulation is involved. To do otherwise could, as the Illinois Pollution Control Board noted in one case, "destroy the force of the regulations and encourage excessive litigation. Moreover, if the costs and benefits are anywhere near equal, simple fairness dictates that the burden should be borne by those who profit from the polluting operation rather than by the innocent neighbors." 126 The Board defined the words "unreasonable" and "arbitrary" in the Illinois pollution statute to create a strong presumption in favor of coinpliance: "A variance is to be granted only in those extraordinary situations in which the cost of compliance is wholly disproportionate to the benefits; doubts are to be resolved in favor of denial." 127 Such an approach ensures that the norms of economic survival and of "ought implies can" are exphcitly considered, but it does so by inaximizing the broad policy goals of the regulatory program.

\section{Fairness Exceptions.}

Fairness exceptions niay be granted even when coniphance is technologically, economically, legally, and inedically possible. ${ }^{128}$ There are three primary bases for such exceptions: (1) the comparative regulatory costs borne by a particular firm are disproportionately higher than those borne by other similarly situated firms; (2) the regulation unintentionally penalizes a firm's recent good-faith activities; and (3) the regulatory costs imposed on a firm by a particular rule, though not necessarily requiring a shutdown, simply are not worth the minimal social benefits that coinpliance would produce. In other words, though the costs involved do not jeopardize the economic viability of the firm, and

126. EPA v. Lindgren Foundry Co., 1 Ill. PCB 11, 16-17 (1970), quoted in Currie, supra note 91, at 412 .

127. Id., quoted in Currie, supra note 100, at 413.

128. Requests for fairness exceptions often include economic hardship claims. Such requests may be granted even if the stronger criteria of an economic hardship claim cannot be met. In effect, fairness exceptions allow an administrator to "do equity" in borderline economic hardship cases where relief nonetheless seems appropriate. See notes 130 and $141 \mathrm{infra}$. 
therefore do not justify an economic-hardship exception, the rule as applied to the petitioner is nevertheless unreasonable.

Two of these types of exceptions have constitutional analogues. The first type of exception, comparative fairness, is a form of regulatory equal protection; the second type is a form of regulatory estoppel; and the third type is a form of regulatory substantive due process.

\section{Equal Protection Exceptions.}

Maxim: Equity does not allow a regulatory program to impose a disproportionate share of the regulatory burden on ouly one or a few entities.

Equal protection or comparative fairness exceptions may be allowed when a disproportionate share of the regulatory costs of a particular program falls on one or a few of the affected individuals or entities. Statutes permitting rehef from an "unfair distribution of burdens" often provide the authority to grant comparative exceptions. ${ }^{129}$ These statutory provisions function like regulatory equal protection clauses. They authorize exceptions for those firms able to show that their regulatory costs are disproportionately higher than those borne by others. Disproportionate costs or unequal burdens alone, however, are not sufficient for relief. As the Department of Energy guidelines have indicated:

exception rehef has been approved where a showing is made by a firm that in addition to experiencing a greater adverse impact as a result of a regulatory provision as compared to other firms, the nature or extent of the adverse impact on the firm significantly impedes its operations . . ., frustrates one of the policy objectives [of the statute] ... or or places it in a substantially different position from other similarly situated firms . . . . 130

Thus, for example, in the early days of the oil price and allocation program International Aviation Industries sought exception relief from a price ceiling imposed on aviation fuel. ${ }^{131}$ Although controls allowed

129. See, e.g., Energy Policy and Conservation Act, 42 U.S.C. § 6393(a)(4) (1976).

130. 41 Fed. Reg. 50,856, at 50,858 (1976). Requests for equal protection exceptions are often combined with economic-hardship claims. In one sense, an economic hardship claim is the same as an equal protection claim. It is an "unfair distribution of burdens" if a particular regulation, though costly to all regulated firms, actually forces sone firms out of business. An equal protection exception, however, nay also be appropriate where a firm's compliance with a rule will not necessarily force the firm out of business, but the costs of compliance are greatly disproportionate to those borne by similarly situated firms. An equal protection rationale provides an additional basis for granting and justifying exception rehef, particularly in cases where the hardship claim is relatively weak.

131. International Aviation Indus., Inc., [1975 Transfer Binder] ENERGy MGMT. (CCH) (2 FEA) If 80,562 (March 26, 1975). 
only one cent per gallon to be passed on to consumers, Aviation sought an increase of four cents per gallon to reflect certain non-product cost increases it had incurred since the price-control prograin becaine effective. ${ }^{132}$ The Administrator found that "Aviation's total non-product costs had increased by $29.73 \%, \ldots$ an increase far in excess of the 1 cent per gallon that the company by regulation was permitted to pass on. ${ }^{133}$ The Administrator granted inost of the exception rehef requested, notimg that strict compliance with the applicable regulations would result in an unfair distribution of burdens on the firm. ${ }^{134}$ In other words, the one-cent maximum was inucl harder on Aviation than on its competitors, whose own product costs had not risen as greatly or as quickly.

Marathon Oil v. $D O E^{135}$ involved stronger comparative fairness claim. Ashland Oil Co. depended heavily on Iran for its supply of crude oil. The government's decision to terminate relations with Iran resulted in a substantial loss of supply to the Ashland refinery. ${ }^{136}$ Ashland petitioned for exception relief to require other refineries to furnish it with approximately 80,000 to 100,000 inore barrels of oil per day. The Administrator granted the relief, noting that Ashland was being asked to bear a disproportionate share of the inandatory allocation program. ${ }^{137}$ In upholding this order, the district court chided Maratlion Oil and Ashland's other competitors, statimg: "It is unfortunate that, at a time of national distress. . . an apparently equitable burden-sharing program should be resisted on the theory that those who relied on Iran for their oil supplies should be left to shift for themselves."138 In short, both the Department of Energy (DOE) and the the reviewing court agreed that Ashland should not be asked to bear alone the consequences of the Iranian embargo. In granting Ashland's exception, the DOE ordered nine refineries to provide a total of 80,000 barrels of

132. As DOE guidelines point out:

[p]rice increases in excess of base prices - which are based solely on the cost of crude oil and petroleum product costs - are allowed if they can be justified on the basis of increased non-oil costs. Categories of increased non-oil costs that refiners nay pass through as price increases imclude the costs of refinery fuels, labor, additives, marketing, utilities, pollution control equipment, containers and interest.

Non-product Cost Increases, 1 ENERGY MGMT. (CCH) \ 3108.

133. International Aviation Indus., Inc., [1975 Transfer Binder] ENERGY MGMT. (CCH) (2 FEA) If 80,562, at 80,704 (March 26, 1975).

134. Id. The Administrator found, however, that a price increase of 2.27 cents per gallon rather than the four cents requested would be sufficient to meet the company's problems. Id.

135. 482 F. Supp. 651 (D.D.C. 1979). For a discussion of this case, see note 123 supra.

136. Ashland alleged that more than $25 \%$ of its supply came from Iran. 482 F. Supp. at 652.

137. $I d$.

138. $I d$. at 655 . 
crude oil per day to Ashland. ${ }^{139}$

The principle underlying the equal protection exception is equality. If regulatory costs are to be imposed, they should be spread as equally as possible. Phrased negatively, administrative equity should discourage regulatory free riders. Such exceptions generally are not allowed if the unequal impact arises froin a firm's own weakness or poor management skills. Assuming, however, that the inequality results from the disproportionate effect of a specific regulation, exception relief may be granted.

The equal protection or coinparative exception infuses a kind of "bill of rights" into the unwritten "regulatory constitution." Though one may not expect Congress to equalize the impact of its programs, one expects a fair administrator to try to do so. An important part of the legitimacy and perceived fairness of any regulatory program is its acceptability to the regulated industries concerned. Because the regulated may not imitially support regulation, basic fairness within a regulatory regime is a sine qua non for acceptability and legitimacy. Comparative exceptions are relatively confined; like economic-hardship exceptions, however, causation can be problematic. 140 Once causation is established, however, the extent of the disproportionate regulatory burden and its effect on a particular company or entity can usually be determined. ${ }^{141}$ The standard of comparison-other coinpeting firms-is relatively unambiguous, and the financial burden incurred by the petitioner is usually quantifiable.

\section{Estoppel Exceptions.}

Maxim: Equity may allow an exception to a rule that penalizes a firm for good-faith action taken prior to the rule's existence.

Exceptions can be granted based on the good-faith actions of a petitioner taken prior to the promulgation of the particular rule. Under the broad statutory criterion of "inequity," the DOE has, for example, granted exceptions to firms which had increased their capital investment in facilities for the retail sale of gasoline at a time when they had reason to expect that they could earn a fair return on their investınent. In Leo Anger, Inc., ${ }^{142}$ for example, the petitioner bought a bulk plant and three retail service stations in Victoria, Texas from Texaco, Inc. on

139. Id. at 653 .

140. See notes 78-107 supra and accompanying text.

141. In Marathon Oil the court could specifically point to the differential impact the Iranian embargo had on Ashland Oil as compared to its competitors. 482 F. Supp. at 652 \& n.2.

142. [1979 Transfer Binder] ENERGy MGMT. (CCH)(4 DOE) I] 81,037 (June 18, 1979). 
October 1, 1978. A bank lent Anger the money to purchase the facilities in part because of a provision of the sales agreement with Texaco in which Texaco assigned to Anger the 1972 adjusted base-period allocation of gasoline for these facilities. ${ }^{143}$ Based on this allocation, Anger expected to realize "substantial profits from the sale of motor gasoline in volumes substantially greater than those sold by the previous owner."144

When the DOE later implemented its Standby Allocation Regulations, ${ }^{145}$ Anger was to "receive only the volumes of gasoline which his predecessor purchased" during certain months of 1978, which would amount to only $74 \%$ of the 1972 adjusted base-period volume. ${ }^{146}$ Anger argued that if it reduced its supphies to this degree, "the firm will run out of gasoline during March 1979, and as a consequence it will not receive sufficient revenue to meet its March operating costs." 147 The DOE granted Anger's petition, noting that it would tend to grant this type of exception when the petitioner could show, in part that:

a substantial capital investment was made by a firm with the expectation that the investment would enable the applicant to increase its sales of motor gasoline and thereby realize an economic benefit froin the investment; [and] in the absence of an exception increasing its allocation of gasoline, the firm will not be able to realize the intended benefits of the capital investment and will be adversely affected to a significant degree. 148

The norm underlying this exception is reliance. When acting in good faith and in the ordmary course of business, a firm should be able to rely on the law then in existence. Thus, a firm's decision to expand its retail gasoline operations should not automatically be held against it

143. Id. at 82,652 . Once price has been rejected as the primary means of allocating a scarce good, there must be a legally imposed allocation system. In the oil price control prograins, as in the natural-gas control programs, a base period allocation refers to the amount of fuel sold by a particular supplier or retailer during a particular time period. The agency enacts regulations that focus on a firm's operations as of a certain date. The time period chosen may not be fully representative of the firm's normal operations and, in any event, cannot take into account changes that oceur after the base period has been established. SENATE COMM. ON Gov'T AFF., supra note 93, at 761-65.

144. [1979 Transfer Binder] ENERGY MGMT., (CCH) (4 DOE) If 81,037, at 82,652. In addition to the purchase price, Anger invested $\$ 79,000$ to remodel the facihties and to purcliase additional equipinent. Id.

145. Id. at 82,652 .

146. Id. at $82,652-53$.

147. Id. at 82,653 . Anger's claim thus had an economic hardship aspect. The Administrator enphasized the petitioner's inability to realize a return on its investment as a ground for relief. $I d$. Under the facts of $A n g e r$, an economic hardship exception would not be appropriate, however, because it was not alleged that the rule change would cause an actual shutdown.

148. [1979 Transfer Binder] ENERGY MGMT. (CCH) (4 DOE) I 81,037, at 82,651 (June 18, 1974). 
because it failed to anticipate new legal circumstances. ${ }^{149}$

Estoppel exceptions prevent the inadvertent application of ex post facto rules to petitioners' good-faith actions and allow the administrator to apply the specific rule as if it contained a grandfather clause. These implied exceptions infuse inarket values, such as firm growth and progress, into the regulatory setting and recognize the coexistence of market and regulatory values within a regulatory framework. These values need not be mutually exclusive; regulation should not gratuitously penalize legitimate inarket behavior.

The contamability of estoppel exceptions, however, can present a problem if rehance is given undue importance. Cliange is and always will be a part of the legal landscape. Granting exceptions simply because change is unforeseen would undermine the effectiveness of any regulatory scheme. Estoppel exceptions should be limited to situations in which the underlying goals and policies of the rule suggest that, in the case in question, compliance was not intended in the first place. The administrator, im granting estoppel exception relief, should correct obvious oversights im the rule in question and "grandfather forward" legitimate behavior.

\section{Reasonableness Exceptions.}

Maxim: Equity may allow an exception when compliance with a rule either does not further the goals of the statute or minimally advances those goals at a cost to the petitioner wholly disproportionate to the benefits produced.

Reasonableness exceptions challenge the substantive validity of a regulation as applied to a particular situation. These exceptions are often authorized by statutory provisions allowing adjustments in the event that application of a rule results in "inequity" or "gross inequity." 150 Exceptions based on a broad notion of mequity are akin to constitution substantive due process claims. ${ }^{151}$ The gist of reasonableness claims is that the regulation as applied to the petitioner is unreasonable because either no significant benefits accrue from coinpliance or compliance im fact has a negative effect on the regulatory pro-

149. In Anger, the company's investment of capital with the expectation that the volume of gasoline allocated under the former base period would remain constant constituted reliance.

150. See, e.g., Policy and Conservation Energy Act, 42 U.S.C. \& 6393(a)(4) (1976). For an application of the "gross inequity" criteria, see Pruet \& Hughes Co., [1975 Transfer Bimder] ENERGY MGMT. (CCH)(2 FEA) If 83,270 (Aug. 25, 1975).

151. The courts have rejected such claims in the area of economic regulation the demise of Lochner v. New York, 198 U.S. 45 (1905), but the rationale of the substantive due process cases remains viable for administrative exceptions processes. 
gram. ${ }^{152}$ For example, in administering oil price and allocation controls, the Federal Energy Administration (FEA) established the practice of granting exception relief from "lower tier" crude oil pricing restrictions when significantly increased production costs left firms witl little or no economic incentive to produce crude oil from existing wells on a developed property. ${ }^{153}$ Though the firms often could not demonstrate serious economic lardship, the exceptions were granted because it was not reasonable to sliut off a source of domestic oil during a time of acute shortages.

Reasonableness exceptions in the energy context reflect the DOE rule that economic liardship be assessed firmwide. 154 Under this approach, large integrated firms usually liave great difficulty ineeting the economic-hardship standard. When exception criteria allow the administrator to rely heavily on policy goals rather than on economic hardship $\mathrm{m}$ individual cases exception relief is possible for a wider class of petitioners. In cases of this kind, reasonableness exception relief en-

152. Viewed broadly, reasonableness exceptions supplement recent administrative reforms requiring agencies to perform cost-benefit studies before issuing new rules. See Exec. Order No. 12,291, 46 Fed. Reg. 13,193, reprinted in 5 U.S.C. \& 601 app., at 124 (Supp. 1V 1980) (establishing procedures for analyzing the impact of proposed and existing regulations on small businesses). Cost-benefit analyses generally assess, however, class-wide costs and class-wide benefits. Reasonableness exceptions allow for a more individualized cost-benefit approach.

The Department of Energy promulgated guidelines setting forth some of the requirements for a showing of "gross inequity":

In evaluating requests for exception relief which are based upon a claim of gross inequity, the FEA has established a number of general standards that reflect a range of criteria which is considerably broader than that applied to claims of serious hardship. The FEA has found a gross inequity to exist, for example, where the application of a specific regulatory provision to a particular factual setting significantly frustrates the realization of a major national energy objective.

... The FEA has also approved exception rehef on grounds of gross inequity where a person is adversely affected in a significant inanner as a result of the apphication of a regulatory provision whose purpose has been seriously distorted by anomalous circumstances.

41 Fed. Reg. 50,856 at 50,857-58 (1976).

153. See, e.g., Pruet \& Hughes Co., [1975 Transfer Binder] ENERgy MGMT. (CCH)(2 FEA) I 83,270 (Aug. 25, 1975), in which the petitioner argued for an exception from the ceiling-price rule of the FEA, because, although coinpliance would not drive the petitioner out of business, it would nonetheless necessitate petitioner's abandonment of certain wells. In alleging gross inequity, the firm argued that application of the rule would undercut an important pohicy goal. The FEA determined that the decline in production levels and the increase in operating expenses under the apphicable rule eliminate any economic incentive to continue production at certain wells. The FEA found further that it was unlikely any other firm would operate these wells and that the nation would thus be deprived of approximately 10,000 barrels of crude oil. The FEA granted exception relief.

For similar oil-pricing cases, see Braden-Deeun, Inc., [1975-76 Transfer Binder] ENERGY Mamt. (CCH) (3 FEA) I 83,072 (Jan. 15, 1976); Energy Dev. Corp, [1975 Transfer Binder] ENERGY MGMT. (CCH)(2 FEA) If 83,309 (Oct. 3, 1975).

154. See, eg., 41 Fed. Reg. 50,856 (1976) (Federal Energy Administration guidelines for exceptions and appeals). 
ables the consequences of partial economic hardship to become worthy of relief.

The basic proposition that individual regulatory costs should be borne for a purpose underlies reasonableness exceptions. Useless or counterproductive regulatory costs resulting in unnecessary individual harm should not be imposed. Regulatory costs that exceed the benefits produced should not be imposed. Similarly, costs should not be imposed if they undermine a statute's goal and produce minimal benefits.

Reasonableness exceptions thus serve as ultmiate rationality checks. If such exceptions are granted only if compliance yields negative or zero social benefits, they are at least capable of containment; however, to the extent reasonableness exceptions become primarily a means of weighing costs and benefits, they conld open the door to endless litigation, delay, and frustration of the agency's regulatory task. ${ }^{155}$ Moreover, the more these exceptions rely on policy, without regard to the peculiar circumstances of tlie petitioner, the more they resemble the policy exceptions outlined below. Given tlie broad and often conflicting goals of most regulatory statutes, the boundaries of policy exceptions are often limited only by the authority that Congress delegates to the administrator. In practice this limitation on administrative discretion is not very meaningful and it can raise some serious procedural issues.

\section{Policy Exceptions.}

Policy exceptions focus less on the mdividual characteristics of the petitioner and more on overall policy goals. Such exceptions are seldom equitable. They are concerned with using the particular to affect the general, ratlier than with conforming the general to the particular. In this respect, they resemble an administrative version of Regents of the University of California v. Bakke ${ }^{156}$ - an adjudicatory dispute between two parties that ultimately became a rulemaking proceeding, with broad and significant policy implications. Yet, policy exceptions can affect the outcome of borderline equitable cases and serve as a means of granting what would otherwise be equitable exceptions. ${ }^{157}$ Policy exceptions are important to this analysis for otlier reasons as

155. The Illinois Pollution Commission has noted the dangers of construing economic-hardship criteria, too hiberally. See text accompanying note 126 supra. Liberal construction of reasonableness criteria involves the same dangers.

156. 438 U.S. 265 (1978). The Supreme Court often acts like an administrative agency, particularly when it promulgates broad policy rules. The Bakke case, for example resembled an administrative rulemaking proceeding. The amicus briefs filed in Bakke numbered well over one hundred and represented interest groups throughout the country.

157. See text accompanying notes 184-95 infra. 
well. For example, they provide an opportunity to explore various nonequitable purposes of exceptions processes such as the promulgation of policy without adherance to formal or complex hybrid rulemaking procedures. Four types of pohicy exceptions emerge: means exceptions, third-party exceptions, national-security exceptions, and public-interest exceptions.

\section{Means Exceptions.}

Maxim: Equity may allow an exception to a rule if its desired results can be or have been achieved by other means.

This exception focuses on the means of compliance with a rule. The Occupational Safety and Health Act (OSHA), ${ }^{158}$ for example, authorizes the Secretary of Labor to promulgate rules and regulations that require employers to take certain specific worker-safety precautions. ${ }^{159}$ If, however, a firm fulfills the basic policy of ensuring safe working conditions by a means at odds with the technical requirements of a safety rule, an exception can be and usually is granted.160 Even though the desired results are achieved by alternative means, the pohicy of the rule is carried out. ${ }^{161}$

The norm underlying the means exception is that substantive results should take precedence over forin and over the means by which one achieves results. Presuniably, regulation is imposed for a purpose. If that purpose can be achieved more efficiently by ways that do not undercut the rule or jeopardize the results the rule seeks to achieve, an exception may be granted. Containability of this kind of exception is seldom a problem as long as the goals of the rule are clear and the proceeding focuses ouly on how those goals will be achieved.

\section{Third-party or Beneficiary Exceptions.}

Maxim: Equity may grant an exception to aid third parties who would otherwise be adversely affected by strict application of the rule to the petitioner.

Exceptions may be granted if the petitioner can show that thirdparty beneficiaries of a regulatory prograin would be better off if the rule in question were not apphed rigorously to the petitioner. Such

158. 29 U.S.C. $\$ \S 651-678(1976)$.

159. Id. $\S 655(\mathrm{a})$.

160. See, e.g., id. $\$ 655(\mathrm{~d})$ and the variances granted by OSHA in Brand Hosiery Co., 39 Fed. Reg. 13,216 (1974) and in Chemico Metals Corp., 39 Fed. Reg. 16,198 (1974).

161. De minimis exceptions can also be included in this category. The basic purpose of the rule is met, though an insignificant exception is necessary to avert a technical violation. 
exceptions place little emphasis on the individual plight of the petitioner and focus on the plight of the purported beneficiaries of a rule.

In James Tidwell Chevron, ${ }^{162}$ for example, the Department of Energy granted an exception to a rule that limited the amount of gasoline Tidwell was entitled to. Tidwell sought an increase in this amount because of his mability to serve his customers. Tidwell's Chevron station had been one of four stations in Nipomo, California. Two stations closed, leaving only Tidwell's station and one other to serve a town of nine thousand people. The Administrator granted the exception request, notimg that the citizens of the town, as third parties, would be greatly inconvenienced by the closing of Tidwell's station at a time of short gasoline supply. The Administrator stated: "The citizens of Nipomo are clearly bearnig a disproportionate portion of the burdens which result from the nation's energy problems. Under the circumstances set forth above, a gross inequity therefore exists which warrants the approval of exception relief." 163

A beneficiary exception imcorporates many of the principles already discussed, but applies them to third parties who may not have standing to seek exception relief. The Tidwell case, for example, represents both a reasonableness or substantive due process exception and a comparative-fairness or equal-protection exception. It is not reasonable or fair to require the residents of Nipomo to drive an extra twenty miles for their gasoline. The nornis of equality and efficiency bolster the reasons for granting this exception. ${ }^{164}$

162. [1980 Transfer Binder] ENERGY MGMr. (CCH)(5 DOE) If 81,262 (June 8, 1979).

163. $I d$. at 83,198 .

164. Id. For a similar third-party case, see Energy Co-op., Inc. [1980 Transfer Binder] ENERGY MGMT. (CCH)(6 DOE) I 81,023 (June 13, 1980).

Aspects of the third-party exceptions are, like many other exceptions, often a part requests such as hardship and fairness exceptions. For example, in Marathon Oil v. DOE, 482 F. Supp. 651 (D.D.C. 1979), an Iranian embargo case, Ashland Oil claimed economic hardship and an unfair distribution of burdens. In addition, the court noted that:

If Ashland is granted no relief, several independent gasoline cnstomers of Ashland in the Midwest will lave to close their stations and lay off many of their employees. It may likewise be expected that industries and small businesses will have to be closed in the Appalachian region, and supplies of heat to homes in that area will have to be curtailed or ended. Northwest Airlines, which receives over 43 per cent of its fuel requirements at Minneapolis-St. Paul from Ashland, will be forced to curtail service by approximately 17 per cent, and Midway Airlines, which receives 100 per cent of its fuel from Ashland, will be forced to ground one-third of its fleet. The Chessie Systein Railroad, which receives approximately 25 per cent of its fuel from Ashland, will be forced to disrupt its freight schedules with resulting curtailment of coal production in Appalachia. According to the Director of the West Virginia Energy and Fuel Office, if Ashland receives an allocation of only 62 per cent, "there is no way that our coal industry is going to be able to survive." Ashland supplies around one-quarter of West Virginia's leating oil, kerosene, and gasoline with potentially disasterous consequences this winter in the event of an oil cut-off. Somewhat similar consequences may be expected in Minnesota.

482 F. Supp. at $658-59$. 
The claims of third parties may be similar to any of those claims already reviewed. The contamability of third-party exceptions thus turns on the peculiar facts of each case. In theory, the only requisite for beneficiary exceptions is that the alleged injury must contravene the intended benefits of the regulatory program.

Of course, this category of exceptions provides another line of attack for a petitioner who is attempting to change the rules for his own benefit. Often, the third-party effects of a failure to grant an exception are combined with other alleged bases for an exception, such as economic hardship, unfair distribution of burdens, or teclnological impossibility. The deprivation of regulatory benefits to third parties should be, however, significant before the petitioner obtains relief in what is otherwise a weak case.

\section{National Security Exceptions.}

Maxim: Equity may allow an exception to a rule to preserve or further national security.

Section 665 of the Occupational Safety and Health Act authorizes the Secretary of Labor to allow "reasonable variances, tolerances, and exemptions" from any provisions of the Act "as he may find necessary and proper to avoid serious impairment of the national defense."165 What constitutes "serious impairment of national defense" is unclear. There is precedent for such an exception, however, in first amendment cases in which constitutional rights have been balanced agamst national security concerns. In Greer v. Spock, ${ }^{166}$ for example, the Supreme Court upheld the government's ban of political speecls on military bases. The ban was a content-based restriction of a fundamental first amendment right that probably would have been flatly impermissible in a civilian context. ${ }^{167}$ Similarly, in Brown v. Glines, ${ }^{168}$ the Court upheld Air Force regulations imposing a prior restraint on the first amendment right to petition. The regulations were intended to ensure military discipline and morale. ${ }^{169}$

Although the allegedly protected speech in botls of these first amendment cases had a direct affect on military matters, OSHA safety

165. 29 U.S.C. $§ 665$ (1976).

166. 424 U.S. 828 (1976).

167. See id. at 842,845 (Powell, J., concurring).

168. 444 U.S. 348 (1980).

169. See id. See also Snepp v. United States, 444 U.S. 507, 509 n.3 (1980) (condoning prior restrictions on publication in the interest of national security "that in other contexts might be protected by the First Amendmeut"); United States v. MacIntosh, 283 U.S. 605, 622 (1931) (breadth of war powers permits Congress to take a variety of actions that would be constitutionally prohibited in nondefense contexts). 
regulations are not likely to affect military morale or discipline so directly. Safety regulations, however, are more likely to affect the efficiency with which certain tasks, useful to the military, are accomplislied. To the extent, for example, that certain safety regulations delay the production of needed weapons or parts for weapons, a national-security exception may be appropriate. Unless these exceptions are limited to times of war, there is hittle to contain them.

\section{Public-interest Policy Exceptions.}

Maxim: Equity may grant an exception to enable an agency to pursue policy goals that are in the public interest and that are not inconsistent with the regulatory goals of the program.

Public-mterest policy exceptions can be authorized by a variety of statutory terms. The Powerplant and Industrial Fuel Use Act of 1978 (PIFUA), ${ }^{170}$ for example, prohibits certaim newly constructed utilities from using natural gas or oil as fuel for producing electricity. ${ }^{171}$ Before its repeal, the Act also required that certam presently existing utilities convert from oil and gas to coal by $1990 .{ }^{172}$ In the interim, there were strict limitations on the amount of natural gas and oil that plants could use, if such plants had alternative-fuel capability. ${ }^{173}$ Section 311 of the Act provided, however, that the administrator could grant "teinporary exemptions" for a period of at least six months, renewable only once, if he determined the exception to be in "the public interest" and consistent with the purposes of the Act. ${ }^{174}$ Pursuant to this provision, the

170. 42 U.S.C. $\$ \S 8301-8483$ (Supp. III 1979).

171. Id. $\S 8311$.

172. Id. $\S 88341-8343$.

173. On August 13, 1981, President Reagan signed into law the Omnibus Budget Reconciliation Act of 1981, Pub. L. No. 97-35, 95 Stat. 357. This Act included various amendments to the Powerplant and Industrial Fuel Use Act. Of particular importance was the repeal of those portions of the PIFUA that prohibited existing powerplants from using natural gas after 1990 as well as using natural gas in excess of certain base-year quantities. See Omnibus Budget Reconciliation Act of 1981, Pub. L. No. 97-35, $\S 1021$, 95 Stat. 614 (repealing Powerplant and Industrial Fuel Use Act of 1978, Pub. L. No. 95-620, $\S 301,92$ Stat. 3305). As a result, existing powerplants are no longer subject to any restrictions on burning natural gas. See id.

174. See 42 U.S.C. \& 8321(c) (Supp. III 1979). In contrast to the open-end approach of this exception, section 8321(c) also allows essentially a hardship exemption to the statutory requirement that powerplants use coal rather than natural gas or petroleum if,

despite diligent good faith efforts -

(1) it is likely that an adequate and rehable supply of coal or other alternate fuel of the quahty necessary to conform with design and operational requirements for use as a primary energy source will not be available to such powerplant or installation at a cost (taking into account associated facilities for the transportation and use of such fuel) which, based upon the best practicable estimates, does not substantially exceed the costs, as determined by rule by the Secretary, of using imported petroleum as a primary cnergy source;

(2) One or more site limitations exist which would not penmit the operation of such a powerplant or any other alternate fuel as a primary energy source; or 
administrator had allowed a number of exeinptions permitting utilities to burn natural gas rather than coal. One proposed Departinent of Energy order stated that as a matter of national energy policy, "to the extent that the near-term choice for fuels for certain existmg powerplants is limited to petroleum or natural gas, the use of natural gas is preferred over petroleum." 175

The Federal Aviation Act ${ }^{176}$ contains a statutory authorization similar to that contamed in the P1FUA. The Aviation Act authorizes the administrator to "grant exemptions from the requirements of any rule or regulation prescribed under this subchapter if he finds that such action would be im the public interest."177 As one court has noted, this standard does not require that an exception be granted if the individual petitioner appears entitled to it for hardship or other personal reasons: " 'public interest' language of the statute authorizing exeinptions would seem to direct a primiary emphasis on the elimination of anoinalies and inequities ... rather than on the alleviation of personal hardship cases." 178

Public-imterest exceptions are also generated by criteria such as "inequity" or "special hardships."179 Though they also generate reasonableness exceptions, ${ }^{180}$ these criteria generate policy exceptions when the focus shifts from the reasonableness of a rule as apphed to a particular entity to the policy goals to be achieved by the exception.

In American Agri-Fuels Corp. ${ }^{181}$ for exainple, the petitioner sought a new suppher and an allocation of unleaded motor gasoline. ${ }^{182}$ The petitioner did not seek the request because of any unique hardship or peculiar circumstances other than his willingness to use this allocation to make gasohol. The administrator granted the rehef, noting:

In previous cases, the DOE has approved exception relief on gross inequity grounds upon a showing that these important national en-

(3) the prohibitions of sections 8311 or 8312 of this title could not be satisfied without violating applicable environmental requirements.

175. 45 Fed. Reg. 18,429 (1980). To further its national energy policy, the DOE proposed to issue hundreds of temporary public-interest exemptions from the prohibitions of section 301 of the PIFUA to facilitate the use of natural gas instead of petroleum in existing electric powerplants. Section 301 of the PIFUA has simce been replaced by a new section 301 set forth in the Omnibus Budget Reconciliation Act of 1981 . See note 173 supra.

176. 49 U.S.C. $\S \S 1421-1432$ (1976).

177. Id. § 1421(c).

178. Starr v. FAA, 589 F.2d 307, 312 (7th Cir. 1978).

179. See 42 U.S.C. \$ 7194(a) (Supp. III 1979).

180. See text accompanying notes $150-55$ supra.

181. [1979 Transfer Binder] ENERGY MGMT. (CCH)(4 DOE) q 81,139 (Feb. 16, 1979), aff d, Amoco v. DOE, 490 F. Supp. 1016 (D.D.C. 1980).

182. For a similar exception based primarily on broad policy grounds, see Bonnaffons $v$. DOE, 492 F. Supp. 1276 (D.D.C. 1980). 
ergy objectives would be significantly frustrated by the DOE Regulations. ...

In the particular circumstances presented in this case, we find that the operation of the allocation regulations results in a gross inequity by preventing a new independent marketer, AAF, frow entering the petroleum industry. In the absence of exception relief assigning AAF a supplier of motor gasoline, the firm will be unable to locate an assured supply of that product and will therefore be unable to conduct the busimess for which it was formed. . . .

Furthermore, we have concluded that the application of the allocation regulations to the circumstances presented by AAF will impede the development of alternative domestic energy sources. Since the shortage in petroleum products resulting from the OPEC Embargo in October 1973, it has been the consistent pohicy of the United States to encourage a diversity of energy sources in order to meet the nation's energy needs. . . .183

In short, exception relief was granted because of the value to national energy policy of the petitioner's willingness to produce an alternative energy source, not because of the peculiar plight of the petitioner.

\section{Analysis of Policy Exceptions.}

The principles underlying public-interest exceptions vary considerably depending on the regulatory goals of the prograin. In the context of economic regulation, such exceptions often infuse market values into a regulatory sclieme that substantially rejects market results. Of fundamental miportance to the grant of the exception in American AgriFuels, Inc. was the need for "entry of new firms," the need for "new energy sources," and the need for the exception to allow the firm to carry out its purpose for going into business. The exception reflects a concern for competition and innovation. Similariy, the public-interest exceptions to the PIFUA allow utilities to act in accordance witl market conditions by using less expensive natural gas ratler than switching to coal.

Policy exceptions thus provide an important ineans of tempering excessively rigid regulatory schemes. Moreover, because sucli exceptions are usually granted on a case-by-case basis, they provide agencies with opportunities to experiment with new approaches before einbarking on wholesale revisions of their rules. But such exceptions can be over-used because their containability is usually restricted only by the broad regulatory goals of the statutes themselves.

Used to excess, policy exceptions can have a profound substantive and procedural impact on any regulatory prograin. Policy exceptions

183. ENERGY MGMT., supra note 181 , I 81,139, at 83,068 (citations omitted). 
that emphasize the need to encourage oil production, for example, can result in substantial decontrol of crude oil prices despite the absence of any amendments to the price-control rules presumably in effect. Though changes in the rules or experimentation on a case-by-case basis can be useful, overreliance on exceptions as a means of initiating new policy can seriously undermine the rules "on the books." 184 The net result may be one set of rules for public consumption and another set consisting of a variety of case-by-case exceptions for the benefit of the more sophisticated, that is, the regulated. This may place reality at odds with the apparent law. ${ }^{185}$

Policy exceptions can infuse a regulatory scheme with new approaches, experimental techniques, and a healthy dose of market reality. But rapid clianges in a regulatory program can cause disruption, higher regulatory costs, ${ }^{186}$ and, in extreme cases, a regulatory repeal of

184. See Madison, OHA's Goldstein: A Bureaucratic Mastermind, Legal Times of Wash., July 9, 1979, at 5, col. 1; Burdick, Obscure, Bristly Energy Official: A Power Center, Legal Times of Wash., July 31, 1978, at 1, col. 2.

185. Cf. Anderson, The Roller-Coaster Income Tax, PUB. INTERest Q., Winter 1978, at 17 (discussing how the many exemptions in the Internal Revenue Code create a system at odds with the goals of progressive taxation).

186. See Mayton, The Legislative Resolution of the Rulemaking Versus Adjudication Problem in Agency Lawmaking, 1980 DUKE L.J. 103. See also Consumers Power Co. v. FEA, [1974-1978 Transfer Binder] EnERgY MGMT. (CCH)(Court Decisions) II 26,078 (D.D.C. July 8, 1977) (residual-fuel entitleinents program upheld; "the hearing procedures of the Administrative Procedure Act are satisfied if the notice of proposed rulemaking contains a description of the subjects and issues involved, which the FEA notice did, notwithstanding the fact that the exact terms the agency adopted were not included in the initial proposal," id. I 26,078, at 26,607; Shell v. FEA, [1974-1978 Transfer Binder] ENERGY MGMT. (CCH) (Court Decisions) I 26,083 (D. Del. Sept. 8, 1976) (unleaded gasoline price regulations issued by the FEA struck down as violating the rulemaking procedures of the FEA Act, which require a ten day comment period on the proposal and an opportumity for oral presentations if the proposal is likely to have a substantial inupact on the industry); DOE Gasoline Allocation Program: Hearings Before the Permanent Subcomm. on Investigations of the Senate Comm, on Governmental Affairs, 96th Cong., 2d Sess. 148-49 (1980)(remarks of Jack Blum, General Counsel to Independent Gasoline Marketer's Council):

the entire process by which regulations are promulgated in the federal administrative law system lias been stood on its head. Instead of using hearings, public participation and careful draftsmanship to prevent problems and insure compliance, DOE counts on the delegation of vast powers to a "Mr. Fix-It" for solutions. All decisions in a way become arbitrary and capricious because not all cases can be handled in a tinely fashion and the results follow no predictable standard.

The office [of Hearings and Appeals] was given an extraordimarily broad delegation of power from the Secretary of Energy and, in effect, gave Mr. [Melvin] Goldstein the opportunity to take policy initiatives as he crafted acceptable relief for people who had been imjured or were about to be injured by the regulations of the Econounic Regulatory Administration. He also has showed himself willing, and at times eager, to take on policy issues which the Economic Regulatory Administration had ignored.

Id. (footnotes omitted).

During these hearings, Professor Mayton stated:

Problems develop. . . when the exceptions device is employed to a different end, that of formulating law or policy to be applied to the industry. The OHA exceptions process, 
the statute that originally spawned the exceptions. ${ }^{187}$

Policy exceptions have procedural as well as substantive ramifications. Most agencies grant or deny exceptions by using either formal or informal adjudicatory procedures. To the extent that granting exceptions through adjudication becomes a major policymaking tool, one of the major administrative reforms in recent years-the movement away from adjudicatory procedures toward ruleınaking procedures to make poliey ${ }^{188}$ — inay be undermined.

There are a number of reasons why policy exceptions may undermine this reform. First, broad delegations of legislative power to agencies tend to produce general rules that fail adequately to resolve significant policy conflicts. ${ }^{189}$ The inherent difficulty of legislating for the future and of formulating rules in areas of scientific uncertainty 190 militate in favor of general prohibitions that can be more carefully defined at a later date through an exceptions process. Given the ambitious and difficult nature of some regulatory programs, the use of exceptions to adjust such programs may be a wise way to proceed; however, overreliance on exceptions as a backup to generalized rulemaking may encourage incoinplete and careless rulemaking. The temptation to

then, can be, and is, used to make new law, or rules, rather than merely providing exceptions to existing rules. . . . [Texaco, Inc. v. DOE, 460 F. Supp. 339 (D.D.C. 1978)]. The problems occasioned by developing industry-wide policy, or rules, by an exceptions process rather than the rule making process are not just procedural oddities. Rather, when the rule making process is subverted by ad loc agency decisions, certain serious institutional problems start to einerge.

DOE Gasoline Allocation Program Hearings, supra, at 153-54.

Professor Mayton concluded that broad exception processes present a lost of problems:

1. Undermining the congressional goal of establishing a secure set of published standards to provide guidance to the regulated industry ..... When standards are not secure-when the exception becomes the rule-imdustry incurs imcreased risks which result in increased costs, which are eventually passed on to the public.

2. [C]reation of a certain litigious state within an industry $-a$ conditiou whicl eveutually imposes, in economic terms, serious "transaction costs." If the standard is rendered infirm by an exceptions process, then busimess will predicate its judgment on the exceptions it can procure. Hence, the case load subject to the exception process increases - dramatically.

3. [T] he exception process itself may (1) cliange the status quo and (2) operate as a prejudgment when the exceptions process rather than rule making is resorted to initially to develop policy.

4. The exception process [1nay not provide] the broad data base that Congress requires by the rule making process.

Id. at 154 .

187. Regulatory repeal may very well be the case with the public-interest exceptions granted pursuant to the Powerplant Industrial Fuel Use Act, 42 U.S.C. $\$ \$ 8301-8483$ (Supp. III 1979). As noted above, this Act has been significantly amended by the Omnibus Budget Reconciliation Act of 1981, Pub. L. No. 97-35, 95 Stat. 357.

188. See 1 K. Davis, Administrative Law Treatise $\$ 1.9$ (2d ed. 1970).

189. See Stewart, The Reformation of American Administrative Law, 88 HARv. L. REv. 1669, 1673-1702 (1975).

190. See Pedersen, Formal Records and Informal Rulemaking, 85 YALE L.J. 38, 58 (1975). 
provide a rough-and-ready rule and use the exceptions process to complete the task on an individualized basis may be too great to avoid.

Increased procedural complexity, particularly for agencies that must use complicated hybrid procedures, also encourages agencies to bypass rulemaking procedures. Promulgating rules pursuant to new hybrid approaches can be a tedious process. ${ }^{191}$ For example, using a substantial-evidence standard to test the validity of rules and allowing cross-examination before formulatimg them can render the entire rulemaking process exceedingly cumbersome. ${ }^{192}$ It took a number of years to promulgate just a few rules dealing with toxic substances. ${ }^{193}$ And the Magnuson-Moss Act, which establishes hybrid rulemaking procedures for the FTC, has been an administrative nightmare. ${ }^{194}$ The use of an exceptions process to develop policy avoids the complexity and the time-consuming aspects of general rulemaking under these new approaches. It also shields the policymaking process and its ultimate results from the public at large.

Nevertheless, to the extent that exceptions become the cuttimg edge for policymaking, ${ }^{195}$ two procedural requirements should be a part of any exceptions process. First, policy exceptions that are granted to a class or to a large number of applicants for more than an experimental period of time (for example, six months) should automatically trigger a rulemaking proceeding. The contimued validity of exceptions granted prior to the conclusion of that proceeding should be contingent on the ainendment of the relevant rules. Second, individual equitable proceedings that do not result in major policy changes should nevertheless be suminarized and assessed on a regular basis. These summaries should then be published and, to the extent the incremental changes have produced a significant amendment of a rule, a rulemaking process should be convened to update the rule. The law expressed im an agency's rules should represent reality rather than past regulatory approaches no longer in effect for those with the means and ability to request an exception.

191. B. Boyer, Phase II Report on the Trade Regulation Rulemaking Procedures of the Federal Trade Commission 51-87 (June 1980) (Report to Administrative Conference of the U.S., on file at Duke University Law Library).

192. See generally S. Breyer \& R. Stewart, Administrative LaW AND Regulatory PolICY $499-530$ (1979); McGarrity, Substantive and Procedural Discretion in Administrative Resolution of Science Policy Questions: Regulating Carcinogens in EPA and OSHA, 67 GEO. L. J. 729 (1979).

193. See generally, McGarrity, note 192 supra.

194. See generally Boyer, supra note 191, at 51-87.

195. See note 186 supra. 


\section{Exceptions Processes, the Regulatory Dialogue, and AGENCY CAPTURE}

Exceptions processes provide a ready mechamism for reconciling market, regulatory, and agency values inherent in any regulatory scheme. In effect, exceptions processes create an ongoing interplay between the market and the agencies charged with regulating the market. When regulated entities are granted exceptions to rules of general applicability, questions of agency capture may arise. ${ }^{196}$ This section examines the nature of the regulatory dialogue inherent in exceptions processes and the relationship between a hively exceptions process and the possibility of agency capture.

\section{A. Administrative Equity and the Regulatory Dialogue.}

Individual exceptions cases often present agencies with ambiguous factual patterns that call into play the rationales for various types of exceptions. The apphication of these exception types provides an opportunity for the agency, the hitigants, and reviewing courts to consider and manipulate the principles that underlie each type of exception. The end result is a process best described as a "regulatory dialogue"the interplay that occurs among market, regulatory, and agency values in the resolution of a particular case. The Ashland Oil case, ${ }^{197}$ discussed above, provides a good illustration of this dialogue.

Ashland Oil applied for exception relief to minimizc the impact of the United States' refusal to purchase Iranian oil. Ashland relied on Iran for twenty-five percent of its supply. It argued that the presidential proclamation requiring the refusal was part of the overall regulatory program and, as such, represented an unfair distribution of regulatory burdens, created an economic hardship for the company whose economic extinction threatened to undermine the competitive structure of the oil-refining industry, and constituted gross inequity. ${ }^{198}$

196. See note 209 infra.

197. Marathon Oil Co. v. DOE, 482 F. Supp. 651 (D.D.C. 1979). The Marathon Oil or Ashland case is discussed in note 123 supra.

198. See 482 F. Supp. at $657-60$. In denying the plaintiff' motion for an injunction against Ashland's exceptions, the court stressed the need for Ashland to survive:

[T] he public interest, as expressed on congressional enactments, favors an equitable sharing of the burdens resultimg from the world-wide and national oil shortage. Congress has also indicated that it favors the effective survival of the so-called independent, alongside the huge, multimational integrated oil companies, as one means for maintaining a measure of competition in the oil industry. All of these interests are incoinpatible with an injunction that would allow these planitiffs to escape sharing the burdens flowing from the ban on imports from Iran and would thrust these burdens instead on a coinpany which, in good faith, and in reliance on U.S. government policy decided to procure its crude oil froin that country.

Id at 660 . 
Ashland thus invoked the regulatory values that the oil-allocation program intended to foster-the protection of industries from sudden, unforeseeable change; the need to impose a sharing arrangement among competitors when unforeseen calamity strikes; and the need to nnamtam the competitive market structure by helping an otherwise strong company through a particularly trying, albeit short, time period. Underlying Ashland's economic arguments was the fundamental claim that it is not only unfair, but also unwise, to allow an unforeseen event to put a viable company out of business. Ashland based its arguments on a strong appeal for stability and for the preservation of the competitive status quo. ${ }^{199}$ Survival of the fittest may be an appropriate longterm standard; in the short run, however, administrative equity should not allow the unpredictable action of an unstable country to destroy an otherwise competitive firm and to affect adversely an entire industry.

Marathon Oil and Ashland's other coinpetitors opposed exception relief because it was their oil that Ashland sought to share. The coinpetitors' arguments strongly reflected inarket values, particularly freedom of choice and a willingness to allow the consequences of unforeseen events to run their natural course. ${ }^{200}$ Ashland's decision to deal with Iran, they argned, was a voluntary business judgment from which it was entitled to reap any resulting rewards or suffer any resulting harms. ${ }^{201}$

Agency values usually parallel the values of the regulatory program the agency administers. Agency values include the agency's need to establish, maintam, and enhance its own legitimacy, power, and effectiveness. Though the agency nust work within the ambit of its enabling statutes, it usually has broad discretion. A politically sensitive agency will seek to strike an acceptable balance between market and regulatory values to enhance its credibility with Congress, the beneficiaries or constituents of the programs it administers, and the regulated industries or individuals. This delicate balance produces a mix of market and regulatory values.

In the Ashland case, the agency could liave easily demied Ashland's request by finding that there was no causal connection between

199. Id.

200. See id. at 655.

201. Id. As the Marathon court noted:

Plaintiffs finally contend on this aspect of their motion that the real cause of Ashland's problems - and that of its customers-is that company's discretionary business decision not to maintain worldwide crude oil operations, that is, to fail to develop secure sources of supply, but to rely instead upon the crude oil supplies of Iran. With respect to that decision, plaintiffs state that, "Ashland, not its competitors, must bear the conseId. quences ...." and exception relief is therefore not appropriate. 
the regulatory program and the rehef sought. The agency needed, however, to prove its usefulness at a time when its price and allocation controls were under intense criticism. ${ }^{202}$ The agency also wanted to avoid disruptive economic affects on the beneficiaries of the oil-allocation program. ${ }^{203}$ The agency prevented disruption to third-party beneficiaries by spreading out the effects of a sudden shortage at the expense of Ashland's competitors.

The Ashland Oil case illustrates both positive and negative aspects of an active exceptions process. The case shows how a process that facilitates the interplay of values can produce a healthy fiexibility by infusing with a sense of reahty what could otherwise have become a rigid regulatory regime. Exceptions processes enable an agency to assess straight-forwardly the perceived unreasonableness of the individual costs that rules impose on particular regulated entities. By using exceptions processes to individualize the effects of rigid rules, agencies can decrease the number of frivolous or weak challenges to the procedural or constitutional validity of rules, appropriately limit the scope of pre-enforcement judicial review to questions of law, and render unnecessary some of the more radical attempts to annend the Administrative - Procedure Act, such as the elimination of the presumption of validity that agency rules now enjoy. ${ }^{204}$ Finally, an exceptions process that encourages individualization can also reduce the need for costly enforcement proceedings as a means of rule interpretation and agency pohicymaking.

202. See, e.g., Erickson, Peters, Spann \& Tese, The Political Economy of Crude Oil Price Controls, 18 NAT. RESOURCES J. 787 (1978). Critics had persistently argued that controls decreased domestic production of oil, increased American dependency on foreign oil, and gave false pricing signals to consumers. See, e.g., Bartlett, There Is No Fuel Like Enough Fuel, 25 INST. ON OIL \& GAS L. \& TAX'N 247 (1974).

203. 482 F. Supp. at 658-59. The agency sought to avoid other third-party effects as well. As the court noted in affirming the administrator's decision in Ashland:

[T] he record before OHA shows immediate and substantial injury to many of Ashland's customers. If Ashland is granted no rehef, several independent gasoline customers of Ashland in the Midwest will have to close their stations and lay off many of their employees. It may likewise be expected that industries and small businesses will have to be closed in the Appalachian region, and supplies of heat to homes in that area will have to be curtailed or ended.

482 F. Supp. at 658-59.

204. See, e.g., the "Bumper's Amendment," first introduced in the Senate as S. 2408, 94th Cong., 1st Sess. (1975). For a general discussion of the problems of eliminating the presumption of validity that attaches to agency rules, see R. Levin, Judicial Review and the Bumpers Amendment, in CURRENT IsSUES IN Regulatory ReForm 264 (M. Rosenberg \& B. McGovern, eds. 1980).

The Administrative Conference of the United States opposed the elimination of the presumption of validity. See Rec. 79-6, Elimination of the Presumption of Vatidity of Agency Rules and Regulations in Judicial Review, as Exemplified by the Bumpers Amendment, 54 Fed. Reg. 2308 (1980). 
As the Ashland Oil case also illustrates, exceptions processes can have potentially negative effects as well. Procedural problems may arise particularly when exceptions are used to formulate policy and to substantially amend a regulatory scheme. ${ }^{205}$ There are also problems with balancing individual costs and benefits ${ }^{206}$ and witl determining causation. ${ }^{207}$ It may also be argued that exceptions processes encourage the undesirable capture of the agency by the regulated. But even if we accept the premises of the agency capture doctrime, ${ }^{208}$ it need not occur, particularly if there is an active and primcipled exceptions process.

\section{B. Exceptions and the Capture Doctrine.}

The capture doctrime posits an agency ultimately dominated by the industry it sets out to regulate. ${ }^{209}$ The beneficiaries of the regulation-

205. See text accompanying notes $188-95$ supra.

206. See notes $98-107$ supra and accompanying text.

207. See note 123 supra.

208. Capture theories are vulnerable in many ways. See, e.g., the authorities cited in note 209 infra.

209. Marvin Bernstem describes this process as "clientalism," "[t]he repeated identification of the public interest with a particular private interest" caused by "the dependence of an agency on the support and consent of the regulated." M. BERNSTEIN, REGULATING BUSINESS BY INDEPENDENT COMMISSION 270 (1955). Emmette Redford liolds that a "mature" regulatory agency loses both political and public support, "becomes part of the status quo and thinks in terms of the protection of its own system and its own existenee and power against substantial change." E. REDFORD, ADMINISTRATION OF NATIONAL ECONOMIC CONTROL 386 (1952). Bernstein notes:

In the period of naturity, . . [ [t] he commission becomes more concerned with the general health of the industry and tries to prevent changes whicli adversely affect it. Cut off from the mainstream of political life, the commission's standards of regulation are determined in the light of the desires of the industry affected. It is unlikely that the commission, in this period, will be able to extend regulation beyond the limits acceptable to the regulated groups.

The close of the period of maturity is marked by the commission's surrender to the regulated. Politically isolated, läcking a firm basis of public support, lethargic in attitude and approach, bowed down by precedent and backlogs, unsupported in its demands for inore staff and inoney, the commission finally becomes a captive of the regulated groups.

M. BERNSTEIN, supra at 87-90. James Landis referred to this capture process as "industry orientation":

It arises primarily from the fact that of necessity contacts with the industry are frequent and generally productive of intelligent ideas. Contacts with the public, however, are rare and generally unproductive of anything except complaint. . . .

Irrespective of the absence of social contacts and the acceptance of undue lospitality, it is the daily machine-gun-like impact on both agency and its staff of industry representation that makes for industry orientation on the part of inany honest and capable agency inembers as well as agency staffs.

Chairman of Subcomm. on administrative Practice and Procedure of the Senate COMm. ON the Judiciary, 86Th CONG., 2D Sess., Report on Regulatory Agencies to the President-Elect 71 (Comm. Print 1960) (J. Landis).

Many cominentators who have written on the subject of capture go further and assert that the regulatory process is necessarily ineffective, except when the agency is part of the executive branch 
consumers, for example-are short-changed because the agency eventually puts the imterests of the regulated ahead of the interests of those whom the agency was established to protect. ${ }^{210}$ The capture doctrine is mapposite, however, when the regulations involved cut across several industries. $^{211}$ Diversity among an agency's regulatory constituency

of government. The thesis of these writers is that regulated interests readily capture the independent regulatory agency, that independence takes the agency out of politics, and that the only way a regulatory agency can resist the pressures of the regulated is through strong political support froin the executive branch. See, e.g., P. APPELBY, Policy AND AdMINISTRATION 161-64 (1949); M. BeRnSteIn, supra, at 155-63; J. FesleR, The INDEPENDENCE of STATE Regulatory Agencies 64 (1942); R. Noll, Reforming Regulation 100 (1971); J. Pfiffner \& R. Presthus, Public Administration 480 (3d ed. 1953); E. REDFord, supra, at 289; D. TRUMAN, The GovernmenTAL Process 416-21 (1955); Cutler \& Johnson, Regulation and the Political Process, 84 YALE L.J. 1395, 1397-1402 (1975).

Professor Kenneth Davis disagrees with this theory of executive protection for two reasons: (1) only a portion of the statutes administered by the regulatory agencies are designed primarily to contravene the interest-and even then the purposes of those statutes are often mixed or unclear; (2) executive policies vary widely, much of the time adding up to indifference to the regulatory programs. Davis suggests that "the key to effective administrative resistance to pressures of regulated groups is not presidential supervision of the regulators but is continued congressional and presidential support for administrative aggressiveness." $1 \mathrm{~K}$. DAVIS, AdMINISTRATIVE LAW TREATISE § 1:03, at 22-23 (1958).

Richard Posner, on the other hand, finds the capture theory unsatisfactory because it lacks any theoretical foundation:

No reason is suggested for characterizing the interaction between the regulatory agency and the regulated firm by a inetaphor of conquest, and surely the regulatory process is better viewed as the outcome of implicit (soinetimes explicit) bargaining between the agency and the regulated firms. No reason is suggested as to why the regulated industry should be the only interest group able to influence an agency. Customers of the regulated firm have an obvious interest in the outcoune of the regulatory process-why inay they not be able to "capture" the agency as effectively as the regulated firms, or inore so? No reason is suggested as to why industries are able to capture only existing agencies-never to procure the creation of an agency that will promote their interests-or why an industry strong enough to capture an agency set up to tame it could not prevent the creation of the agency in the first place.

Posner, Theories of Economic Regulation, 5 BeLl J. OF ECON. \& MGMT SCI. 335, 342 (1974).

Posner also contends that the "theory" is contradicted by three bodies of evidence.

First, not every agency is characterized by a pristine virtue; often there is no occasion for conquest. . . .

Second, the theory has no predictive or explanatory power at all when a single agency regulates separate industries having conficting interests . . . .

Third, the capture theory ignores a good deal of evidence that the interests promoted by regulatory agencies are frequently those of customer groups rather than those of the regulated firms themselves.

\section{Id. at 342 .}

Fimally there has been sharp criticism of Marvin Bernstein's unuch-quoted and widely read attack on the regulatory agencies. Coinunentators have charged that Bernstein does not thoroughly analyze any commission or agency, but instead Bernstein bases his comments on findings of others. See I K. Davis, Administrative Law Treatise § 2:9, at 94 (2d ed. 1978).

210. See Bernstein, supra note 209 , at 90.

211. This outcome suggests that capture theories explain very little of what actually occurs at the agency level. As Barke and Ricker have pointed out:

The deepest problem with the capture theory is that it does not imply an inconsistent public policy. On the contrary, it suggests that ultimately policy nakes sense in terms of 
makes it more difficult for the agency to be "captured" by any one particular industry. Capture theories imply a certain consistency and even rigidity in agency policy. One of the likely results of an active exceptions process, however, is the systematic undermining of any purely monohthic view of agency policy.212

On the other hand, however, if the agency is less likely to be captured, it may consequently exhibit less care in assessing the costs and benefits of its proposed regulations. For example, if Consolidated Edison Gas and Electric Company were to go bankrupt, it would not be difficult to blame the public service commissioners who denied its latest rate increase request. But if a firm or an industry experiences difficulty because of numerous agency regulations, general economic conditions, increased international competition, outdated technology, and low productivity, it is difficult to hold any one agency accountable. Rather than furthering agency capture, the exceptions process encourages responsible regulation by forcing agencies to accept responsibility, on a case-by-case basis, for the effects of their rules. In short, allowing exceptions on a case-by-case basis implies neither an abandonment of principle nor agency capture, but rather provides a systematic approach for ensuring the flexibility that a fair regulatory program should possess.

\section{CONCLUSION}

We live in an age of regulatory reforn. Debate on regulation focuses more and more on the wisdom and efficacy of traditional governmental approaches to regulatory problems. Two roads diverge in this debate. One leads to supergovernment, with its broad and pervasive regulatory approaches, and the other leads to outright deregulation or, where this is not feasible, to regulation that is as inobtrusive and as market-oriented as possible. ${ }^{213}$

a single goal or interest . . . . The capture theory implies consistency of policy which is neither observed nor intellectually defensible in a democratic pohty.

R. Barke and W. Ricker, A Pohtical Theory of Regulation with soine Observations on Railway Abandonments 34 (March 1981) (Johns-Manville Studies on Regulation, Discussion Paper No. 8008, on file at Duke Uiriversity Law Library).

212. See notes 196-209 supra and accompanying text.

213. See, e.g. ABA Comm. on LAw ANd the Economy, Federal Regulation: RoAds to REFORM 35 (Aug. 1978 Draft). Recommendation 1 states:

In lieu of governmental intervention in the cconoiny, reliance sliould be placed when feasible upon the coinpetitive inarket as regulator supported by antitrust laws. If governmental regulation is required, consideration should be given to disclosure or to incentivebased modes of regulation before turning to the classical command and control modes.

Id. at 35. See also Maloney \& Yandle, Bubbles and Efficiency: Cleaner Air at Lower Cost, REGULATION, May-June 1980, at 49. 
This article has dealt with exceptions that arise from traditional regulatory programs characterized by command-control standards and specific rules. ${ }^{214}$ It has derived certain administrative equitable maxims by examining the fundamental norms that underlie administrative exceptions. As the inarket mechanism becomes an increasingly attractive regulatory tool, questions arise concerning the future role of administrative equity. 215

Arguably, the validity and effectiveness of inarket-oriented rules will not depend on legal exceptions processes. The market is presumably capable of making its own adjustments. The application of marketoriented rules to particular situations, however, will not always advance a prograni's regulatory goals and in some cases may undercut those goals. ${ }^{216}$ Certain individuals or entities may experience hardship

214. See note 11 supra.

215. In FCC v. WNCN Listeners Guild, 450 U.S. 582 (1981), the Supreme Court considered the validity of a Federal Communications Commission (FCC) policy statement that concluded that "the public interest was best served by promoting diversity in entertainment programming by relying exclusively on market forces and competition among broadcasters. . . ." Id. at 585. The Commission, therefore took the view that any change im entertainment progranming was not a material factor to be considered in ruling on an application for license renewal or transfer. Though the Commission recognized that reliance "on the marketplace would not achieve a perfect correlation between listener preferences and available entertainment programming, it, nevertheless, concluded that "the marketplace alone could best accommodate the varied and clianging tastes of the listening public." Id at 596. The Supreme Court found that sucli an approach was fully in accord with the public interest standard of the Communications Act, and that predictions concerning the viability of a market approach were "within the institutional competence of the Commission." Id

In dissent Justices Marshall and Brennan argued that the FCC's deregulation of radio format and rehance upon market forces to ensure diversity in radio programming ignored the need for exceptions. Id. at 608-09. The dissenting Justices stated that the FCC's deregulation policy lacked the flexibility usually required under general regulations, and that "an agency's discretion to proceed in complex areas through general rules is intimately connected to the existence of a 'safety valve' procedure that allows the agency to consider applications for exemptions based on special circumstances." Id. at 609 . The failure to provide for an exception procednre, therefore, was sufficient grounds to declare the FCC's market-oriented deregulation policy defective as a inatter of law.

The majority exphcitly rejected the minority's argument, stating that though the Court had considered the validity of FCC rules in light of the need for flexibility, the Court had never lreld that the FCC may never adopt a rule that lacks an exception provision. Id. at 601, n.44.

216. For example, as the dissent in FCC v. WNCN Listeners Guild noted with regard to the FCC's market approach to programming:

The Policy Statement completely forecloses any possibility that the Commission will reexamine the validity of its general policy on format changes as it apphies to particular situations. Thus, even when it can be conclusively demonstrated that a particular radio market does not fnnction in the manner predicted by the Commission, the Policy Statement indicates that the Commission will blindly assume that the proposed format change is in the "public interest." This result would oceur even where reliance on the market to ensure format diversity is shown to be misplaced, and where it thus appears that action by the Commission is necessary to promote the public interest in diversity.

450 U.S. at 609. 
or (more likely) fail to realize fully the intended benefits of a regulatory scheme. A consequent need to conform the general to the particular is likely to arise.

The inost likely petitioners for such exceptions will be the purported beneficiaries of the rules, not those being regulated. ${ }^{217}$ The relief sought will resemble a structural injunction or, in effect, a "minirule" that imposes regulation that is more stringent than the market approach. Relief will be granted when, in the opinion of the administrator, application of the general market-oriented approach fails to advance the basic goals of the rule. Such exceptions will be policyoriented and akin to the third party beneficiary exceptions discussed above. Rather than argue that the rule in question imposes undue regulatory costs, petitioners will argue that they experience hardship due to the failure of the rule to achieve its goals.

Despite such differences, explicit statutory authorization for such exceptions should be encouraged. This new exceptions process will spark the regulatory dialogue by helping to infuse a market-oriented regime with equitable, rather than purely market-oriented, values. It will encourage the evolution of a regulatory scheme that rejects the overinclusive regulatory approach of traditional command-control regulation. In the place of traditional command-control regulation will arise a regulatory scheme that relies heavily on the market, with exceptions tailored to situations that demand nore stringent regulation than the market provides. 218

On whatever end of the regulatory spectruin we begin-the free market or a complete rejection of the market-an examination of administrative equity suggests that an ongoing interplay of various market and regulatory values will occur and temper the dominant tendencies of whatever regulatory scheme is in effect. A regulatory regime based primarily on market principles will not be a static one. The

217. For example, the respondents in FCC v. WNCN Listeners Guild, who had petitioned for review of the FCC's policy statement in the United States Court of Appeals for the District of Columbia Circuit, were a number of citizens groups purportedly interested in "fostering and preserving particular entertainment formats." 450 U.S. at 585.

218. For example, rather than command-control standards to ensure safety in the workplace, a regulatory scheme may rely primarily on injury taxes - an employer would be taxed according to the safety record of the firm. Strict reporting requirements would be necessary, but such an approacl would eliminate the necessity on the part of the regulator of knowing details of every firm. The inaximum injury tax did not significantly alleviate chronic safety problems, an exception or mini-rule could focus on the peculiar situation causing these problems. A least common denominator or "bad apple" approach would be avoided. Rather than treating all firms as incapable of solving their own problems, stringent regulation would be reserved for a selectcd few. Such exceptions would begin to resemble the kinds of federal court decrees notcd earlier. See text accounpanying notes 4-8 supra. 
regulatory dialogue will continue and, given the basic values that pervade any regulatory scheme, the underlying structure of these new approaches will remaim very much the same. 
- 